NBER WORKING PAPER SERIES

\title{
FATHERS AND YOUTH'S DELINQUENT BEHAVIOR
}

\author{
Deborah A. Cobb-Clark \\ Erdal Tekin \\ Working Paper 17507 \\ http://www.nber.org/papers/w17507 \\ NATIONAL BUREAU OF ECONOMIC RESEARCH \\ 1050 Massachusetts Avenue \\ Cambridge, MA 02138 \\ October 2011
}

Part of this research was conducted while Erdal Tekin was a visiting professor at the Australian National University. Chandler McCellan provided excellent research assistance. This research uses data from Add Health, a program project directed by Kathleen Mullan Harris and designed by J. Richard Udry, Peter S. Bearman, and Kathleen Mullan Harris at the University of North Carolina at Chapel Hill, and funded by grant P01-HD31921 from the Eunice Kennedy Shriver National Institute of Child Health and Human Development, with cooperative funding from 23 other federal agencies and foundations. Special acknowledgment is due Ronald R. Rindfuss and Barbara Entwisle for assistance in the original design. Information on how to obtain the Add Health data files is available on the Add Health website (http://www.cpc.unc.edu/addhealth). No direct support was received from grant P01-HD31921 for this analysis. The views expressed herein are those of the authors and do not necessarily reflect the views of the National Bureau of Economic Research.

NBER working papers are circulated for discussion and comment purposes. They have not been peerreviewed or been subject to the review by the NBER Board of Directors that accompanies official NBER publications.

(C) 2011 by Deborah A. Cobb-Clark and Erdal Tekin. All rights reserved. Short sections of text, not to exceed two paragraphs, may be quoted without explicit permission provided that full credit, including (C) notice, is given to the source. 
Fathers and Youth's Delinquent Behavior

Deborah A. Cobb-Clark and Erdal Tekin

NBER Working Paper No. 17507

October 2011

JEL No. J12,J13,K42

\begin{abstract}
$\underline{\text { ABSTRACT }}$
This paper analyzes the relationship between having one or more father figures and the likelihood that young people engage in delinquent criminal behavior. We pay particular attention to distinguishing the roles of residential and non-residential, biological fathers as well as stepfathers. Using data from the National Longitudinal Study of Adolescent Health, we find that adolescent boys engage in more delinquent behavior if there is no father figure in their lives. However, adolescent girls' behavior is largely independent of the presence (or absence) of their fathers. The strong effect of family structure is not explained by the lack of paternal involvement that generally comes with fathers' absence, even though adolescents, especially boys, who spend time doing things with their fathers usually have better outcomes. There is also a link between adult delinquent behavior and adolescent family structure that cannot be explained by fathers' involvement with their adolescent sons and is only partially explained by fathers' involvement with their adolescent daughters. Finally, the strong link between adolescent family structure and delinquent behavior is not accounted for by the income differentials associated with fathers' absence. Our results suggest that the presence of a father figure during adolescence is likely to have protective effects, particularly for males, in both adolescence and young adulthood.
\end{abstract}

\author{
Deborah A. Cobb-Clark \\ Melbourne Institute of Applied Economics \\ and Social Research \\ Faculty of Business and Economics \\ The University of Melbourne \\ Parkville VIC, 3010 Australia \\ and IZA \\ d.cobb-clark@unimelb.edu.au \\ Erdal Tekin \\ Department of Economics \\ Andrew Young School of Policy Studies \\ Georgia State University \\ P.O. Box 3992 \\ Atlanta, GA 30302-3992 \\ and NBER \\ tekin@gsu.edu
}




\section{Introduction}

Over the past fifty years, modern families have been indelibly altered by dramatic increases in the prevalence of non-marital childbearing, divorce, and remarriage. In the United States, for example, nearly four in ten births are to unmarried women (Ventura 2009) and the fraction of children under age 18 living in mother-only families has risen from 8 percent in 1960 to 23 percent in 2010 (U.S. Census Bureau 2010). Overall, 30 percent of U.S. children are estimated to spend some time living in stepfamilies (Bumpass et al. 1995). This dramatic trend toward father-absent families is similar in most countries around the world and has focused the attention of policy makers and researchers alike on the important role that fathers play in child and adolescent development. For example, the 1996 welfare reform legislation in the United States places significant emphasis on family structure by incorporating family formation and the maintenance of two-parent families as one of its primary components. Most recently, President Obama signed into law the Claims Resolution Act of 2010, which authorizes $\$ 150$ million for programs promoting healthy marriages and responsible fatherhood.

Previous research has shown that fathers' involvement with their children is linked to higher academic achievement, improved social and emotional well-being, and a lower incidence of delinquency, risk taking, and other problem behaviors. ${ }^{1}$ However, it appears to be the quality -- rather than the frequency -- of fathers' interaction with their children that matters, making it vital to study fathers' relationships with their children in depth (see BronteTinkew et al. 2006).

Much of the early research assessed the role of fathers in two-parent families (e.g. Harris and Marmer 1996; Harris et al. 1998; Hofferth 2006; and references cited therein), leaving many questions about the consequences of living with biological fathers versus

\footnotetext{
${ }^{1}$ For reviews see Harris and Marmer 1996; Amato and Rivera 1999; and Bronte-Tinkew et al. 2006.
} 
stepfathers and the contributions of non-residential fathers unanswered. In the intervening years, non-residential fathers and stepfathers have become the focus of substantial research effort (see White and Gilbreth 2001; King 2006; Yuan and Hamilton 2006), though the literature on each has developed somewhat separately. Research on stepfathers typically ignores children's relationships with their non-residential fathers, while research on nonresidential fathers often does little more than simply account for the fact that mothers may have remarried (King 2006). ${ }^{2}$ Importantly, the handful of studies which do account for the full complexity of children's family relationships paint a much more cautious picture about the positive consequences of fathers' engagement with their young and adolescent children. Kalil et al. (2010) find that living in closer proximity to ones biological father after divorce is associated with poorer outcomes in young adulthood, for example. Yuan and Hamilton (2006), conclude that a close, non-conflictual relationship with stepfathers improves adolescent outcomes, however "involvement with non-residential fathers provides little benefit for adolescents and may even be detrimental" (p. 1209). ${ }^{3}$ Similarly, economists attempting to unravel the separate effects of family breakdown on young people often conclude that what matters most when fathers leave is not the loss of their presence per se, but rather the loss of their income (Painter and Levine 2004; Walker and Zhu 2007).

Our goal is to contribute to this emerging literature by assessing the impact of biological fathers, both residential and non-residential, and residential stepfathers on the likelihood that youth will engage in a range of delinquent behaviors including property crime, violent crime, selling drugs, taking part in gang fighting, and a composite measure of criminal activity. We allow fathers to influence youths' behavior through (i) the amount of time they spend doing things with and talking to young people; (ii) the contributions they

\footnotetext{
${ }^{2}$ Much of the literature on non-residential fathers seems to be about the relationship between child support payments and access to children (e.g., Ermisch 2008; Del Boca and Ribero 2003).

${ }^{3}$ King (2006) analyzes the same data source as Yan and Hamilton, but is somewhat more optimistic about the role of non-residential fathers. She finds that while close relationships with both non-residential and stepfathers are associated with better outcomes, it is the relationship with the stepfather that is more influential.
} 
make to household income; and (iii) simply being present in the household. We are particularly interested in the following questions: How does the incidence of delinquent behavior vary across family structures? Does spending time with or talking to fathers reduce the likelihood that youth will engage in delinquent behavior? Finally, does accounting for the extent to which fathers are involved with young people help us to understand the link between youths' delinquent behavior and the types of families they are growing up in?

In addressing these questions, we analyze data from the National Longitudinal Survey of Adolescent Health (Add Health). This data set is ideal for our purposes for a number of reasons. Unlike previous researchers, we exploit the longitudinal nature of the Add Health data to minimize concerns about reverse causality -- i.e., the possibility that delinquent behavior may influence fathers' involvement. Moreover, the information that is available in Add Health about family structure, the nature of fathers' involvement with their children, and household income allows us to simultaneously consider the multiple pathways through which fathers might matter. Detailed data on family background, in particular, mothers' relationships with their children are also important in minimizing the potential for unobserved heterogeneity to confound our estimates. Finally, we consider delinquent behavior both in adolescence and early adulthood.

Understanding the link between fathers' involvement with their children and youths' delinquent behavior is critical because the decision to engage in risky or criminal behavior often has substantial social, economic, and health costs for adolescents themselves, their families and society more generally. In 2008, for example, U.S. law enforcement agencies made an estimated 2.11 million arrests of young people under the age of 18 (U.S. Department of Justice 2009), while the Centers for Disease Control (CDC) report that youth violence is the second leading cause of death for young people between the ages of 10 and 24 (CDC 2010). Designing sensible initiatives to reduce these costs requires fully accounting for the 
complexity of youths' family relationships and a better understanding of why and how fathers matter.

We find that adolescent boys engage in more delinquent behavior if there is no father figure in their lives. Adolescent girls' behavior is largely independent of the presence (or absence) of their fathers. However, the strong effect of family structure is not explained by the lack of paternal involvement that generally comes with fathers' absence, even though adolescents who spend time doing things with their fathers often have better outcomes. There is also a link between adult delinquent behavior and adolescent family structure that cannot be explained by fathers' involvement with their adolescent sons and is only partially explained by fathers' involvement with their adolescent daughters. Finally, the strong link between adolescent family structure and delinquent behavior is not accounted for by the income differentials associated with fathers' absence.

The remainder of this paper proceeds as follows. In Section 2, we describe our conceptual framework and estimation strategy. We discuss the details of the Add Health data and our estimation sample in Section 3. Our results are presented in Section 4, while our conclusions and suggestions for future research are discussed in Section 5.

\section{Estimation Strategy}

\subsection{Conceptual Framework}

We begin with a simple conceptual framework in which young adults' decisions to engage in delinquent behavior are driven by the anticipated costs and benefits of their actions. ${ }^{4}$ These costs and benefits are influenced in part by the parental investments made while they were growing up. In light of the dramatic changes in family structure over the past generation, we are also interested in understanding the consequences of fathers'

\footnotetext{
${ }^{4}$ We build on the work of Becker (1968) which underpins many models of crime and risk taking.
} 
investments (or lack of investments) during adolescence on their young-adult children's delinquent behavior.

We assume that fathers influence their children through three primary channels. First, the financial resources they bring to the household are used to fund critical investments in children's development, health, education, psychosocial skills, and so on. These human capital investments raise the returns to productive market work and stable family structures when children reach adulthood, thus reducing the benefits and increasing the opportunity costs of delinquent behavior. Second, fathers spend time and effort in raising their children which is likely to have long-term consequences for children's intellectual and developmental well-being. ${ }^{5}$ Particularly relevant for our purposes is the evidence that fathers can influence adolescent drinking, delinquency, and other problem behaviors (Cooksey and Fondell 1996; Harris and Marmer 1996; Harris et al. 1998; Amato and Rivera 1999; Bronte-Tinkew et al. 2006; Hofferth 2006; Antecol and Bedard 2007; Michael and Ben-Zur 2007). Finally, there is the possibility that fathers may affect their children's future outcomes simply by being resident in the household while they are growing up. Fathers provide children with male role models and can influence children's preferences, values, and attitudes, while giving them a sense of security, boosting their self-esteem, and enhancing their ability to build positive relationships with others. They also increase the degree of adult supervision in the household, which may lead to a direct reduction in delinquent behavior (Wilder and Watt 2002; Aizer 2004; Averett et al. 2009).

Much of the existing literature on the consequences of children's family structure on later life outcomes confounds these pathways. There is a voluminous literature, for example, which concludes that growing up in a single parent household is associated with increased risk taking (e.g. Antecol and Bedard 2007). However, unless researchers separately account

\footnotetext{
${ }^{5}$ See Hofferth (2006) for a review.
} 
for the many ways in which fathers affect their children, estimates of the effect of family structure -- i.e. simple comparisons of outcomes when there is a father present and when there is not -- confound all of them. Moreover, children often live in what are complex family structures and this complexity is often ignored. It is particularly important to consider the nature of fathers' relationships with their children -- i.e. whether residential or not, whether biological or step, etc. -- and to account for the fact that many children have multiple father figures in their lives (see White and Gilbreth 2001).

To formalize these arguments we begin by assuming that the utility of engaging in delinquent behavior $\left(y_{t}\right)$ is given by:

$$
y_{t}=y\left(x_{t}\left(z_{0}, \kappa_{0}\right) ; z_{0} ; \kappa_{0}\right)
$$

where $x_{t}$ captures a young adult's current preferences, market opportunities, family structure, etc. which underlie his or her current costs and benefits of delinquent behavior. Let $z_{0}$ capture adolescent endowments and $\kappa_{0}$ represent the investments that fathers make in their adolescents. In the empirical implementation of the model, we will adopt a linear, latent variable structure for $y_{t}$.

In the simplest case, fathers' influence on adult decision making can be modeled using a binary variable indicating whether or not a father was present in the household while the individual was growing up $\left(f_{0}\right)$. Specifically,

$$
\kappa_{0}=\kappa\left(f_{0}\right)
$$

with $f_{0}=1$ if young adult lived with a father while growing up and $f_{0}=0$ otherwise. This implies that the effect of fathers' investments on young-adult outcomes is given by:

$$
\partial y_{t} / \partial f_{0}=\left[\left(y_{t} \mid x_{t}, z_{0}, \kappa\left(f_{0}=1\right)\right)-\left(y_{t} \mid x_{t}, z_{0}, \kappa\left(f_{0}=0\right)\right)\right]
$$

The effect of fathers on young adults' delinquent behavior can then be estimated by comparing outcomes -- conditional on demographic characteristics and initial endowments -- 
for young adults who grew up in father-present households with the outcomes of those who did not.

We now consider a more complex model of fathers' influence on their children. Specifically, let

$$
\kappa_{0}=\kappa\left(f_{0}, I_{0}^{f}\right)
$$

As before, $f_{0}$ captures fathers' presence during adolescence. Let $I_{0}^{f}$ capture fathers' time and financial investments. Differentiating young adults' outcomes with respect to fathers' presence and then rearranging results in:

$$
\begin{gathered}
\partial y_{t} / \partial f_{0}=\partial y_{t} / \partial \kappa_{0} \partial \kappa_{0}(.) / \partial f_{0} \\
\partial y_{t} / \partial \kappa_{0}=\partial y_{t} / \partial f_{0}\left(\partial \kappa_{0}(.) / \partial f_{0}\right)^{-1} \\
\partial y_{t} \partial_{\kappa_{0}}=\left[\left(y_{t} \mid x_{t}, z_{0}, \kappa\left(f_{0}=1\right)\right)-\left(y_{t} \mid x_{t}, z_{0}, \kappa\left(f_{0}=0\right)\right]\left(\partial \kappa_{0}(.) / \partial f_{0}\right)^{-1}\right.
\end{gathered}
$$

Equation (3') makes it clear that the effect of fathers' presence during adolescents (the first right-hand-side term) on adult outcomes is moderated by the effect that living with ones father has on the total level of paternal investments including fathers' time and income. Our interest is in understanding the relative contribution of each to young adults' delinquent behavior.

\subsection{Estimation Equation}

The above conceptual framework is useful in clarifying the link between family structure in adolescence (as measured by fathers' presence) and young-adult outcomes. We cannot estimate equation (1) directly, however. Instead, we focus on a series of reduced-form 
models -- increasing in controls -- of a young adult's participation in delinquent behavior $\left(Y_{i t}\right)$. We begin by considering our baseline model:

$$
Y_{i t}=\sum_{j=1}^{5} F_{i 0}^{j} \alpha_{t}+Y_{i 0} \theta_{t}+\varepsilon_{i t}
$$

where $i$ indexes individuals, period 0 coincides with wave 1 and $t=1,2$ indexes waves 2 and 4 respectively. The effect of fathers' presence in their adolescent children's lives is captured through a set of five mutually exclusive indicator variables reflecting family structure, $F_{i 0}^{j} j=1 \ldots 5$, i.e. the specific configuration of father figures that each child had in wave 1 (see Section 3.2). We also account for the effect of delinquent behavior in adolescence $\left(Y_{i 0}\right)$ on the propensity to engage in subsequent delinquent behavior. The inclusion of a lagged dependent variable in equation (4) is intended to provide a simple proxy for any unobserved factors that are correlated both with adolescent family structure and subsequent delinquent behavior. ${ }^{6}$ Consequently, $\alpha_{t}$ captures the total effect of alternative adolescent family structures -- characterized by differences in father figures -- on post-adolescent delinquent behavior controlling for whether or not an individual engaged in delinquent behavior as an adolescent. Finally, $\varepsilon_{i t}$ is a normally distributed error term with mean zero and unit variance.

Estimates from this baseline model will be compared to those from a model in which we also account for the degree to which fathers are actively involved in their adolescent children's lives. Specifically,

$$
Y_{i t}=\sum_{j=1}^{5} F_{i 0}^{j} \alpha_{t}^{\prime}+\sum_{j=1}^{5}\left(I_{i 0} * F_{i 0}^{j}\right) \beta_{t}+Y_{i 0} \theta_{t}+\varepsilon_{i t}
$$

where $I_{i 0}$ is a vector which includes measures of the time that fathers spend doing things with and talking to their adolescent children. In this case, $\alpha_{t}^{\prime}$ captures the effect of fathers'

\footnotetext{
${ }^{6}$ The inclusion of a lagged dependent variable to control for unobserved factors is not ideal, but is commonly done when instruments are not available (e.g. Cesur et al. 2011; Rees and Sabia 2011). In particular, Wooldridge (2003) argues this procedure can improve estimates of the effects of policy variables on various outcomes (pg. 301).
} 
presence in their adolescent children's lives -- i.e., the effect of fathers who spend no time talking to or doing things with their children -- while $\beta_{t}$ reflects the additional effect of fathers' engagement with adolescents on post-adolescent delinquent behavior.

Finally, we also consider a specification which also controls for i) total household income; ii) mothers' engagement with their adolescents; and iii) standard demographic controls (age, race and ethnicity, immigrant status, religion, number of siblings, birth order, and health status). These additional controls allow us to sharpen our understanding of the effects of fathers' presence and fathers' involvement in adolescents' lives. Accounting for total family income is particularly important as this allows us to separate the income effect of living with a father from the supervisory or role model effects of fathers. ${ }^{7}$ Moreover, previous research points to the importance of accounting for mothers' involvement with their children when assessing the effect of fathers on child outcomes as mothers may increase the time and effort they devote to children as a means of compensating for fathers' lack of engagement (Amato and Rivera 1999; Bronte-Tinkew et al. 2006). Finally, we include standard demographic controls to account for variation in the relative costs and benefits of delinquent behavior. ${ }^{8}$

Our ability to use the panel structure of the Add Health data allows us to overcome some of the econometric challenges faced by previous researchers. In particular, our ability to estimate the effect of father figures during adolescence on delinquent behavior in young adulthood diminishes concerns about reverse causality and constitutes an important improvement over previous research which attempts to estimate the effect of family structure on simultaneous outcomes using cross-sectional data. Yuan and Hamilton (2006), for example, find "few beneficial associations between non-residential-father involvement and

\footnotetext{
${ }^{7}$ Unfortunately, the Add Health data do not allow us to construct a measure of fathers' income separate from total household income.

${ }^{8}$ We restrict ourselves to controls that are plausibly exogenous and are not themselves a function of past delinquent behavior (see Ruhm 2004).
} 
adolescent well-being" (pg. 1205). Yet the interpretation of these cross-sectional associations are made difficult by the potential for family structure itself (for example, parental separation) or parental involvement (for example, parental supervision) to respond to adolescent behavior (for example, youth drug taking). Moreover, we are able to use lagged delinquent behavior as a proxy for the unobserved factors that are correlated with adolescent family structure, but continue to drive delinquent behavior in young adulthood. ${ }^{9}$

\section{Data}

The data used in this study come from the National Longitudinal Study of Adolescent Health (Add Health) which was administered by the Carolina Population Center at the University of North Carolina at Chapel Hill. The first wave of Add Health was administered between September 1994 and April 1995 to 20,745 nationally-representative adolescents in grades 7 through 12 . An in-school questionnaire was given to every student who attended one of the 132 sampled U.S. schools. A random sample of approximately 200 adolescents from each high school/feeder school pair was selected for in-home interviews. Three follow-up interviews have been conducted since the original Add Health data collection. The first follow-up interview (wave 2) was administered in 1996; wave 3 was conducted in 2001 when

\footnotetext{
${ }^{9}$ Although the panel nature and richness of Add Health allow us to control for a large set of covariates, our analysis is based on observational data rather than a controlled experiment. Therefore, it is possible that we are unable to account for all the factors that are correlated with adolescent family structure and parental involvement on the one hand and delinquent behavior on the other. One way to account for possible bias due to unobserved heterogeneity is to implement an instrumental variables method. However, this would require an instrument that could plausibly satisfy the exclusion restriction, i.e. a variable that is correlated with family structure and paternal involvement, but has no direct effect on young adults' delinquent behavior. Unfortunately, we were not able to identify such a variable in Add Health. We also considered a sibling fixed effects regression as an alternative strategy to account for unobserved heterogeneity. Note, however, that fixed effects models that rely on twins or on full siblings are not useful in our case because there would be no variation in family structure within these sibling pairs. Instead, we did estimate models using the 315 halfsibling, same-sex pairs (150 males and 165 females) with non-missing data in our sample. These sibling pairs share the same mother but have different fathers, i.e. different family structures. Estimating our models including half-sibling fixed effects produced results that were generally similar qualitatively to those presented here. However, the results were imprecisely estimated due to the small sample sizes and lack of variation.
} 
respondents were between the ages of 18 - 26; and wave 4 was administered in 2007 - 2008 to 15,701 of the original Add Health participants. ${ }^{10}$

Add Health is ideal for the purposes of this study for a number of reasons. First, it was specifically designed to provide rich information on adolescents' health and risk behaviors. Therefore, a detailed set of questions revealing information about involvement in delinquent behaviors was asked of the respondents in each wave. Second, it is considered to be the largest and most comprehensive survey of adolescents ever conducted. Third, the longitudinal nature of the Add Health allows us to examine the long-term relationship between family structure and delinquent behavior. Finally, since we have information on delinquent behavior in all waves, we can account for baseline differences in these behaviors in our empirical analyses.

\subsection{Estimation Sample}

We employ data from waves 1,2 and 4 in this paper. ${ }^{11}$ We subject our data to a number of exclusion criteria. Specifically, we delete children living alone or in a foster home in any of the waves. We also delete observations with missing information on the type of father figure or on fathers' involvement. We further limit our analysis sample to those adolescents living with biological mothers in wave 1. Following Add Health data user guidelines, we also drop observations with missing sample weights. Applying these criteria and merging wave 1 with waves 2 and 4 results in an analysis sample of 11,295 adolescents for the combined waves 1 and 2 sample and 11,731adolescents for the combined waves 1 and 4 sample. The age range of adolescents in our analysis sample is between 11 and $21 .^{12}$

\footnotetext{
${ }^{10}$ See Harris et al (2009) for more on the Add Health research design.

${ }^{11}$ We also conducted parallel analysis using wave 3 data. These results are largely consistent with those presented here. For brevity, these results are not presented here, but are available from the authors upon request.

${ }^{12}$ This is the age range in wave 1 . However, it must be noted there are only 78 adolescents at ages 11, 19, 20, or 21 in wave 1, so the overwhelming majority of adolescents are between ages 12 and 18.
} 
Finally, we retained observations with missing data on control variables by creating categories for missing information.

In our models, we control for a set of attributes that may influence individuals' propensity to engage in delinquent behavior. These include binary indicators of age, race, ethnicity, nativity status, health status, religious affiliation, number of siblings, and whether the person is the first child in the family. In some of our analysis, we also control for binary indicators of parental income and mothers' involvement with adolescents. ${ }^{13}$

\subsection{Family Structure}

As we have restricted our estimation sample to only those individuals living with their biological mother in wave 1 , the variation in family structure comes from the various father figures present at wave 1. Given this, our five family structure indicators take on the following values: i) $F_{i 0}^{1}=1$ residential, biological father only and 0 otherwise; ii) $F_{i 0}^{2}=1$ non-residential, biological father only and 0 otherwise; iii) $F_{i 0}^{3}=1$ no father figure and 0 otherwise; iv) $F_{i 0}^{4}=1$ residential, step-father and non-residential, biological father and 0 otherwise; and v) $F_{i 0}^{5}=1$ residential, step-father only and 0 otherwise. In our regressions, $F_{i 0}^{3}$ is omitted and all effects of family structure are measured relative to this group. It is important to note that five indicators span the full set of possible family structures. One of the advantages of the Add Health data is that we have the capacity to take all of them into account. As mentioned earlier, much of the previous literature on the effects of fathers focuses only on a limited set of family structures, combines outcomes across disparate family types, and ignores the interaction between non-residential, biological fathers and residential, stepfathers (see King 2006).

\footnotetext{
13 Descriptive statistics for the independent variables of interest are consistent with those of the relevant literature and are available upon request.
} 
Information about the prevalence of specific family structures is presented in Table 1. Of those adolescents living with their biological mothers, more than 61.6 percent also live with their biological fathers. Consistent with previous U.S. evidence (see Dahl and Moretti 2004; Lundberg 2005), we find that teenage boys are more likely to be living with their biological fathers than are teenage girls. More than one in four adolescents (28.5 percent) in our sample live with a single mother and have a non-residential, biological father in their lives. The likelihood of adolescents having two father figures in their lives (i.e., both a nonresidential, biological father and a stepfather) (7.3 percent) is the same as having no father figure at all (7.1 percent). Finally, a small proportion of young people (2.8 percent) lives with a stepfather only and do not have a relationship with their biological father.

\section{Table 1 Here}

\subsection{Delinquent Behavior}

The Add Health contains many questions related to delinquent and criminal activity in the previous 12 months. These questions are similar to those found in other surveys and to the official definitions of "crime" used by government sources such as the Bureau of Justice Statistics. We focus on a representative set of five types of delinquent behaviors in this analysis. The first four are (i) property crime, (ii) violent crime, (iii) selling drugs, and (iv) taking part in a gang fight in the past 12 months. These comprise most of the delinquent behaviors committed by the adolescents and young adults. Finally, we also analyze a fifth measure which captures whether any of these four delinquent behaviors were committed in the past 12 months. ${ }^{14}$

\footnotetext{
${ }^{14}$ Mocan and Tekin $(2005,2006)$ show that the rates of delinquent behaviors reported in Add Health, e.g. crime and illicit drug use, are comparable to those in other national data sources, while Mocan and Rees (2005) demonstrate that the extent of juvenile crime calculated from Add Health data is similar to that obtained from other sources. Survey administrators took several steps to maintain data security and to minimize the potential for interviewer or parental influence. First, respondents were not provided with any printed questionnaires. Rather, all data were recorded on laptop computers. Second, respondents listened to pre-recorded questions through earphones for sensitive topics such as delinquent behavior. They then registered their answers directly into laptop computers.
} 
More specifically, we define a binary indicator of property crime which equals one whenever an individual committed property damage, theft, or burglary in the past 12 months and zero otherwise. The property damage information is derived from the Add Health questionnaire item: "Did you deliberately damage property that didn't belong to you in the past 12 months?” Theft is derived from two separate questions asking whether or not the respondent stole something worth more than \$50 dollars or worth less than \$50 dollars in the past 12 months. ${ }^{15}$ Burglary is based on the question: "In the past 12 months, did you go into a house or building to steal something?” We also create a binary indicator of whether or not the respondent committed a violent crime (i.e. either assault or robbery) in the past 12 months. Assault is derived from the survey questionnaire: "In the past 12 months, did you hurt someone badly enough to need bandages or care from a doctor or nurse?” Robbery is based on the question: "In the past 12 months, did you use or threaten to use a weapon to get something from someone?” Our indicator for selling drugs equals one whenever respondents report selling marijuana or other drugs in the past 12 months and zero otherwise. Our binary indicator of taking part in a gang fight equals one if the individual took part in a fight with a group of friends against another group in the past 12 months. Finally, we created an indicator for any delinquent behavior which takes the value of one if the respondent reports committing any of these acts in the past 12 months and zero otherwise.

Figures 1 - 5 show the link between delinquent behavior and family structure across waves separately by gender. These figures point to a number of stylized facts. First, delinquent behavior is significantly more common among young men than young women. ${ }^{16}$ Specifically, while just over half of teenage boys (54.3 percent) responded that they had engaged in some form of delinquent behavior in the 12 months prior to wave 1 , this was true

\footnotetext{
${ }^{15}$ The exact wordings of the questions are "Did you steal something worth less than $\$ 50$ ?” and "Did you steal something worth more than $\$ 50$ ?”

${ }^{16}$ The only exception is that young women with both a non-residential, biological father and a stepfather in wave 1 are more likely to be involved in gang fighting in wave 2 than are young men growing up in the same family structure.
} 
of slightly more than a third (37.2 percent) of teenage girls. Second, property crime (i.e. property damage, theft, or burglary) is the most common form of delinquent behavior amongst those surveyed, while selling drugs is the least common. Third, in general, the incidence of delinquent behavior declines sharply as adolescents move into young adulthood. In particular, the incidence of any type of delinquent behavior falls from 54.3 percent for boys (37.2 percent for girls) in wave 1 to 19.3 percent (7.6 percent) in wave 4 . The exception is that the likelihood that young men report having sold drugs in the previous 12 months increases between waves 1 and 2. Fourth, there is substantial variation in the incidence of delinquent behavior among youths living in different family structures, although this pattern depends on gender and the specific form of delinquent behavior considered.

Figures 1 - 5 Here

\subsection{Family Structure and Parental Involvement with Adolescents}

One of the advantages of the Add Health survey is the availability of detailed information about the extent to which parents are involved in various aspects of their adolescent children's lives. Information is separately available for mothers, biological fathers (both residential and non-residential), as well as the stepfather if there is one. We relied on factor analysis to reduce the dimensionality of the measures representing fathers' involvement. ${ }^{17}$ Based on this analysis, we grouped these various survey items into two categories: one involving doing things with the adolescent and the other involving talking with him or her about various issues. Specifically, the former comprises five activities that youths may undertake with their parents and is based on the following questionnaire items: In the past four weeks, (1) “Have you gone shopping?; (2) “Have you played a sport?”; (3) “Have you gone to a religious service or church-related event?”; (4) “Have you gone to a

\footnotetext{
${ }^{17}$ Factor analysis has been frequently used by researchers to reduce the data to a smaller set of dimensions (e.g., Cobb-Clark and Schurer 2011 and Okumura and Usui 2010).
} 
movie, play, museum, or concert, or sports event?”; and (5) “Have you worked on a project for school?" Similarly, the activities involving talking with parents are based on the following four questionnaire items: (1) “Have you talked about someone you're dating, or a party you went to?”; (2) “Have you had a talk about a personal problem you were having?”; (3) “Have you talked about your school work or grades?”; and (4) "Have you talked about other things you're doing in school?” We created separate indexes for mothers, residential fathers, and non-residential fathers by summing up the five (four) binary indicators in the former (later) category. Thus, each index represents the number of activities that youths do with their parents or alternatively the range of issues that youths discuss with their parents.

Table 2 shows how parental involvement varies with family structure. We begin by considering the experiences of adolescents living with two biological parents. On average, those biological fathers who live with their children engage in 1.5 (1.2) different activities each month with their sons (daughters) and talk with their adolescent children about 1.4 issues on average. Thus, biological fathers do significantly fewer things with their daughters while there is no statistically significant difference in the range of things they talk to their sons and daughters about. Mothers, on the other hand, do significantly more things with and talk about significantly more issues with their daughters than they do with their sons.

\section{Table 2 Here}

We then conducted standard t-tests of differences in means to determine whether nonresidential, biological fathers and stepfathers are less involved with their adolescent children than are biological fathers living with their children. The results of these tests are also reported in Table 2. Not surprisingly, we find that non-residential, biological fathers and stepfathers generally do fewer things with their adolescent children than do residential, biological fathers. For example, biological fathers who do not live with their children do on average one activity per month with their sons and 0.8 activities with their daughters 
irrespective of whether there is a stepfather present in the household or not. This is significantly fewer activities than residential, biological fathers are engaged in. Interestingly, however, the range of issues that adolescents talk to their biological fathers about does not in general depend on whether their fathers live with them or not. One exception to this pattern is that adolescent girls talk about more things -- not fewer -- with their biological fathers when they live apart. Finally, stepfathers engage in more activities with their stepchildren than do non-residential, biological fathers, ${ }^{18}$ but talk about fewer things with their stepchildren than do biological fathers who live with their children. In contrast, there are no significant differences in the number of issues that adolescents talk about with their stepfathers versus biological fathers. The pattern is that doing things together is more common when the father figure and the adolescent live in the same household than when they live apart, while the difference is less pronounced for talking about things. This is not surprising given that talking can always take place over the phone, while doing things together requires both the father and the adolescent to be physically present.

Finally, we also tested whether the involvement of mothers with their adolescent children differed significantly by family structure. Irrespective of whether they have been remarried or not, mothers talk about more issues, but engage in fewer activities, with their sons and daughters if their children's biological fathers are not present in the household. Mothers also do not appear to compensate for the complete absence of a father figure by increasing their involvement with their children. In fact, it is those children without a father figure in their lives who engage in fewer activities and talk about fewer issues with their mothers. One possible explanation for this pattern is that these mothers have less time to get involved in the lives of their children as they may be overburdened with other roles and daily activities such as working and shopping in the absence of a father figure.

\footnotetext{
${ }^{18}$ In particular, those children with two father figures spend significantly more time doing things with their stepfathers than with their non-residential, biological fathers.
} 


\section{Results}

Our goal is to understand how fathers' involvement with their adolescent children is related to the tendency for young people to subsequently engage in delinquent behavior. We address this issue by estimating models of delinquent behavior using linear probability models. ${ }^{19}$ Given that Add Health relies on a school-based sample, we cluster standard errors at the school level to adjust for correlations within a school. We consider three specifications increasing in controls in order to isolate the effects of fathers' presence from the effects of the time and income that fathers invest in their adolescents (see Section 2.1). As both the incidence and determinants of risky behavior vary with gender (see Michael and Ben-Zur 2007; Abbott-Chapman et al. 2008), results (OLS coefficients and robust standard errors) are presented separately for young men and young women.

\subsection{Fathers' Influence on Delinquent Behavior in Adolescence}

\subsubsection{Results from our baseline model}

We begin by considering how fathers' involvement with their adolescent children influences subsequent delinquent behavior. Table 3 presents the results from our baseline model (see equation 4) of adolescents' delinquent behavior measured in wave 2 when youth were aged 11 - 21, which controls only for initial (i.e. wave 1) family structure and delinquent behavior.

\section{Table 3 Here}

Not surprisingly, adolescents who have engaged in delinquent behavior in the past are much more likely to do so again. In particular, adolescent boys and girls who report participating in some form of delinquent behavior in wave 1 are approximately 38 percentage points more likely to also report engaging in some form of delinquent behavior in wave 2 .

\footnotetext{
${ }^{19}$ We estimate linear probability models for ease of interpretation. Estimation of our models via probit models yielded similar marginal effects.
} 
The degree of persistence in behavior over time appears to be the lowest for violent behavior (i.e. assault or robbery) and the highest for selling drugs, especially for boys.

Adolescent boys who have a father figure in their lives are significantly less likely to engage in subsequent delinquent behavior than are their peers with no father in their lives. For example, the incidence of any form of delinquent behavior is 7.6 percentage points lower among boys living with their biological fathers and is 8.5 percentage points lower among boys who live with stepfathers and have no relationship with their biological fathers. Delinquent behavior is also somewhat less likely among boys with non-residential, biological fathers whether or not their mothers have remarried (4.0 and 5.0 percentage points, respectively), though the former effect is not significant. Fathers are associated with a particularly large reduction in the incidence of violent behavior and gang fighting among adolescent boys. These effects are quite sizeable given that we are also controlling for whether or not adolescents were engaged in delinquent behavior at the baseline.

The presence or absence of father figures, on the other hand, appears to have little relationship with the chances that adolescent girls will engage in delinquent behavior. Controlling for initial (wave 1) delinquent behavior, girls with non-residential, biological fathers and/or stepfathers in wave 1 are as likely as girls with no fathers to engage in delinquent behavior in wave 2. We find no significant difference in delinquent behavior across these four family structures whether we consider delinquent behaviors separately or as a whole. Only residential, biological fathers appear to be related to a modest reduction in delinquent behavior among adolescent girls. Girls living with their biological fathers are less likely to engage in violent behavior (3.0 percentage points), selling drugs (1.9 percentage points), and gang fighting (4.1 percentage points) than are girls with no fathers. Overall, adolescent girls living with their biological fathers are 3.6 percentage points less likely than 
girls with no fathers to engage in some form of delinquent behavior though this difference is not statistically significant.

\subsubsection{Results from out augmented model}

Next we turn our focus to the results of our augmented model which allows us to assess the relative importance of fathers' presence versus fathers' involvement in understanding delinquent behavior among adolescents. We consider two alternative specifications. The first adds interactions between family structure and fathers' involvement with their adolescent children to the baseline model (see equation 5), while the second also incorporates a number of important controls for i) mothers' involvement with adolescents; ii) family income; and iii) demographic characteristics. Results are reported in Tables 4A and 4B for boys and girls respectively.

\section{Table 4A Here}

Living with a biological father who does not participate in joint activities or talk about any issues is associated with adolescent boys having a 5.5 percentage points lower incidence of any delinquent behavior in wave 2. By way of comparison, the total effect of living with a residential, biological father (as opposed to having no father figure at all) from our baseline model is estimated to be a 7.6 percentage point reduction in delinquent behavior. Similarly, the reduction in specific delinquent behaviors associated with living with ones biological father falls moderately from 6.2 to 4.3 percentage points for violent behavior and only slightly from 7.4 to 7.1 percentage points for gang fighting when we control for the extent of residential, biological fathers' involvement with their adolescent sons. Moreover, the effect of having a non-residential, biological father only (relative to having no father figure) on any form of delinquent behavior remains unchanged once we control for fathers' involvement, while the effect of having both a non-residential, biological father and a stepfather actually 
increases suggesting that in these households fathers' involvement with their sons is associated with increased delinquent behavior. ${ }^{20}$ Finally, controlling for mothers' involvement in their adolescent sons' lives and for differences in household income across family structures as well as exogenous determinants of delinquent behavior do little to change these substantive results (see the even numbered columns in Table 4A).

Parallel results for adolescent girls are reported in Table 4B. Results from our baseline model (see Table 3) indicate that the delinquent behavior of adolescent girls is generally unrelated to the presence or absence of father figures in their lives. The exception is that biological, residential fathers appear to have some modest protective effect in reducing delinquent behavior. This continues to be true once we control for the extent to which fathers are involved in doing things with and talking to their adolescent daughters. Unlike the case for adolescent boys, the incidence of delinquent behavior among adolescent girls in wave 2 is not significantly related to wave 1 family structure once we control for fathers' level of involvement and for delinquent behavior in wave 1 . The single exception is that adolescent girls living with uninvolved, biological fathers are 2.2 percentage points less likely to engage in selling drugs than are girls who have no father figure in their lives. Again, if anything, it is fathers' presence -- as opposed to fathers' involvement -- that appears to be relatively more important for girls.

\section{Table 4B here}

Overall, when taken together our results strongly suggest that much of the overall (baseline) impact of fathers on their adolescent sons' delinquent behavior reflects the effect of fathers' presence rather than their involvement with their sons or the financial contribution

\footnotetext{
${ }^{20}$ We conducted F-tests to assess the joint significance of the family structure and involvement interactions. Results from these tests indicate that most of these interactions are jointly insignificant for both adolescent boys and girls. The only exceptions are the family structure interactions associated with activities involving doing things together with boys in the models of any delinquent behavior and violent crime. For girls, all the interactions are imprecisely estimated.
} 
they make to household income. ${ }^{21}$ Although in most cases there is no link between family structure and the propensity for adolescent girls to engage in delinquent behavior, where we do find an effect, in particular with respect to selling drugs and gang fighting, it is again the case that it is fathers' presence rather than the degree of their involvement that appears relatively more important. In other words, although there are some significant differences in the effect of fathers' involvement in different family structures, these differences contribute little to our understanding of why adolescents' delinquent behavior is so strongly linked to their family structure. This is consistent with Cooksey and Fondell (1996) and Painter and Levine (2004) who also conclude that although the time fathers spend with their children has positive effects on academic performance and high school completion rates, it does little to mediate the effects of family structure. In other words, any negative consequences of fathers' absence do not appear to be explained by a lack of fathers' time per se. Moreover, we have also controlled for household income implying that the effect of fathers' absence on adolescents' delinquent behavior is also not explained by the lack of fathers' income. ${ }^{22}$

\subsection{Fathers' Influence on Delinquent Behavior in Adulthood}

One of the great advantages of the Add Health data is that -- unlike previous researchers -- we have the opportunity to study the effects of adolescent family structure on delinquent behavior in adulthood. The criminological literature establishes that criminal behavior itself is passed from one generation to the next implying that many children simply follow their fathers and mothers into crime (see for example Goodwin and Davis 2011). We know much less, however, about the way that fathers' parenting styles, level of engagement,

\footnotetext{
${ }^{21}$ Yuan and Hamilton (2006) analyze cross-sectional data from wave 1 of Add Health and find that fathers' involvement with their adolescents has no effect on depression and problem behavior.

${ }^{22}$ We have been unable to account for any income transfers that nonresidential, biological fathers may be making to biological mothers. To the extent that higher income is associated with a reduction in delinquent behavior, this would lead us to understate the reduction in delinquent behavior associated with having a nonresidential, biological father as opposed to no father figure.
} 
and relationships with their adolescent children influence their children's criminal activity a decade or more later. Addressing this issue is particularly important given ongoing concerns about crime more generally and the change in the propensity to commit a crime as people age. Figures 1 - 5, for example, demonstrate the sharp decline in property crime, violent crime, selling drugs, and taking part in a gang fight as adolescents become adults making it particularly interesting to understand the extent to which any residual delinquent behavior has links to adolescent family structure.

\subsubsection{Results from our baseline model}

Table 5 presents the results from our baseline model (see equation 4) of young adults' delinquent behavior measured in wave 4 when youth were aged 25 - 32. This model controls only for initial (wave 1) family structure and delinquent behavior when young adults were adolescents aged 11 to 20 .

The results demonstrate the enduring link between living with one’s biological father and a reduced tendency for men to engage in delinquent behavior even in adulthood. Specifically, men who lived with their biological fathers while they were adolescents are 5.1 percentage points less likely than those with no father figure to engage in any delinquent behavior as adults even after accounting for their delinquent behavior in adolescence. Moreover, living with a residential, biological father -- rather than having no father figure -while growing up is associated with lower incidence of a broad range of delinquent behaviors later in life including violent crime (4.1 percentage points), selling drugs (3.5 percentage points), and taking part in a gang fight (2.9 percentage points). Finally, the incidence of

violence among adult men is also lower among those who lived with stepfathers irrespective of whether their biological fathers were present in their lives (3.1 percentage points) or not (4.0 percentage points). 


\section{Table 5 Here}

In all other cases, we find no significant differences in the incidence of delinquent behavior among adult men growing up in alternative family circumstances. It is also the case, that with one minor exception, the presence or absence of father figures in adolescence is unrelated to the incidence of delinquent behavior among adult women.

\subsubsection{Results from our augmented model}

As before, we estimate two augmented models of delinquent behavior that allow us to assess the relative importance of fathers' presence versus fathers' involvement during adolescence in understanding delinquent behavior among adults. The first adds interactions between family structure and fathers' involvement with their adolescent children to our baseline model of adult delinquent behavior (see equation 5), while the second also controls for i) mothers' involvement with their children; ii) family income; and iii) demographic characteristics all measured during adolescence. Results are reported in Tables 6A and 6B for men and women respectively.

\section{Table 6A Here}

Comparing results from our baseline and augmented models indicates that accounting for fathers' involvement with their adolescent sons has no appreciable effect on the relationship between adolescents' family structure and their delinquent behavior in adulthood. In particular, adult men who lived with their biological fathers while adolescents and who, as adolescents, reported that their fathers were not involved in doing things or talking with them, are 5.2 percentage points less likely to engage in any delinquent behavior relative to men with no father figures in adolescence (see Table 6A). In other words, the presence in the household of biological fathers who are uninvolved with their adolescent sons (as measured by our two indices) is associated with a 5.2 percentage point reduction in the incidence of 
delinquent behavior once those sons reach adulthood. This is virtually identical to the estimated 5.1 percentage point total effect of residential, biological fathers on any form of delinquent behavior obtained in our baseline model (see Table 5). Overall, that there is no evidence that fathers' involvement in their adolescent sons' lives mitigates the effects of adolescent family structure on any of the specific forms of delinquent behavior we consider.

The effect of living with a non-involved, biological father during adolescence on adult delinquent behavior is reduced somewhat once we also control for mothers' involvement, household income, and demographic characteristics during adolescence. In particular, the effect of living with a non-involved, biological father -- relative to having no father figure -in reducing the delinquent behavior of adult men overall falls from 5.2 percentage points to 4.0 percentage points and becomes statistically insignificant. The reduction in the effect of living with biological fathers on the chances of adult men engaging in other forms of delinquent behavior is similar. At the same time, accounting for the interaction that men had with their mothers, household income, and demographic characteristics while these men were growing up leaves the effect of other types of family structures on adult crime rates nearly unchanged.

Fathers appear to have a very different effect on the outcomes of their adult daughters. Most importantly, there is no effect of simply growing up with a father figure on the likelihood that adult women engage in delinquent behavior. Women growing up with fathers who are not involved in talking to or doing things with them are as likely to engage in a range of criminal activities in adulthood as women who grew up with no fathers (see Table 6B). Living with a biological father, on the other hand, who is involved in taking his daughter shopping, to soccer games, to church or to movies, etc. does reduce the chances that his adolescent daughter will be involved in delinquent activities once she reaches adulthood. Specifically, each additional activity that a residential, biological father participates in with 
his adolescent daughter results in between a 0.8 and 1.0 percentage point reduction in her chances of engaging in any form of criminal activity. The involvement of residential, stepfathers in their adolescent stepdaughters activities also reduces somewhat the incidence of adult delinquent behavior in some cases. ${ }^{23}$ These results are in sharp contrast to those for adult men who largely benefit from simply having a father figure present during adolescence.

\section{Table 6B Here}

It is also important to note that growing up with only a non-residential, biological father who spent time talking with his adolescent daughter appears to be associated with slight increases in her delinquent behavior as measured by any type of crime, violent crime, and selling drugs once she reaches adulthood. This surprising result may be due to the possibility that these verbal interactions between the non-residential father and the adolescent is an indication of a problematic relationship between the two, which might have manifested itself as delinquent behavior later in life. ${ }^{24}$

Finally, it is important to note that the incidence of criminal behavior is significantly lower among adult men and women whose mothers spent time doing things with them as adolescents. Specifically, each additional activity that mothers' are engaged in with their adolescent sons results in a $1.1(0.7)$ percentage point fall in the likelihood that their sons (daughters) are engaged in any form of delinquent behavior as adults. This suggests that the positive effects of mothers' involvement on child and adolescent outcomes (e.g. Amato and Rivera 1999; Bronte-Tinkew et al. 2006) may continue well into adulthood.

\footnotetext{
${ }^{23}$ Specifically, the incidence of property crime and gang fighting is reduced as stepfathers' involvement increases for women with both residential stepfathers and non-residential, biological fathers in adolescence.

${ }^{24}$ The F-tests revealed that the estimates on the interaction between involvement and family structure are jointly insignificant in almost all cases. The exceptions are that the interactions between family structure and talking are significantly different from zero in the any delinquent behavior model for men and in the violent crime model for women.
} 


\section{Conclusions}

Dramatic changes in the shape of modern families have led to debate about the extent to which stronger relationships between fathers and their children might help in reducing the substantial social, economic, and health costs associated with youths' delinquent behavior. Making progress in developing sensible policy initiatives, however, depends on a much fuller consideration of the complexity of youths' family relationships and a deeper understanding of why and how fathers matter. The loss of a father's income seems to result in poorer outcomes for example, (e.g. Painter and Levine 2004; Walker and Zhou 2007), though there is only mixed evidence that young people suffer from the loss of a father's active involvement in their lives per se (e.g. Kalil et al. 2010; Yuan and Hamilton 2006).

This paper contributes to this emerging literature by using Add Health data to assess the impact of having a father figure on the likelihood that youths will engage in a range of delinquent behaviors later in life. Unlike previous researchers, we consider the full range of possible father figures including residential and non-residential, biological fathers and residential stepfathers. We use the panel structure of our data to: (i) incorporate a lagged dependent variable to control for unobserved factors that are correlated with both family structure and delinquent behavior and (ii) exploit the timing of fathers' involvement with their children to minimize concerns about reverse causality. Our detailed data also allow us to simultaneously consider mothers' relationships with their children as well as the multiple pathways through which fathers might matter. Finally, we consider delinquent behavior both in adolescence and early adulthood.

We find that while adolescent girls' behavior is largely independent of the presence (or absence) of their fathers, adolescent boys engage in more delinquent behavior if there is no father figure in their lives. This latter effect cannot be explained by the lack of fathers' active involvement in their sons' lives per se, however, despite the fact that the time boys 
spend doing things with their fathers often does have beneficial effects. We also find a link between adult delinquent behavior and adolescent family structure that cannot be explained by fathers' involvement in doing things with their adolescent sons and is only partially explained by fathers' involvement with their adolescent daughters. Finally, the strong link between adolescent family structure and delinquent behavior is not accounted for by the income disparities associated with fathers' absence.

These results are consistent with others in the literature and underscore the complexities of designing public policies to reduce youths' delinquent behavior by strengthening their family ties. ${ }^{25}$ Increasing the time that fathers spend being actively engaged with their children would almost surely be beneficial -- especially for boys -- but it seems unlikely to eliminate the disparity in delinquency rates among those who do and do not grow up with fathers. Fathers who spend very little time doing things with or talking to their children have a protective effect in reducing the chances their children will engage in delinquent behavior. This may suggest that the sense of security generated by the presence of a male role model in a child's life has protective effects for the child irrespective of the degree of interaction between the child and the father. At the same time, Bronte-Tinkew et al (2006) argue it is the quality not the quantity of fathers' interaction with their children that matters, while Harris and Marmer (1996) conclude that it is fathers' emotional rather than behavioral involvement which reduces delinquency in poor families. Thus, it is also possible that the measures available to us in the Add health data are simply not refined enough to pick up these distinctions.

It also seems clear that what works for adolescent boys will not work equally well for adolescent girls. This is perhaps not surprising given that both the incidence and

\footnotetext{
${ }^{25}$ Cooksey and Fondell (1996) and Painter and Levine (2004) also find that the time that fathers spend with their children does not mitigate the effect of family structure. Yuan and Hamilton (2006) conclude that adolescent outcomes may be improved by a close relationship with stepfathers, but are not benefited and may be harmed by involvement with nonresidential fathers. Other researchers find small, but positive, effects of paternal involvement (e.g. Amato and Rivera 1999; Bronte-Tinkew et al 2006).
} 
determinants of risk taking vary with gender (see Abbott-Chapman et al. 2008; Michael and Ben-Zur 2007), but it does have important implications. On the one hand, adolescent girls' decisions to engage in delinquent criminal behavior are less closely linked to whether or not there is a father present in their lives. Thus, they may be less sensitive to the increasing trend towards non-marital childbearing, divorce, and remarriage. On the other hand, the weakness of this relationship effectively eliminates one of the levers that policy makers might use in reducing delinquent behavior among girls.

Finally, while income maintenance programs are typically the backbone of any social assistance system, we find little evidence that higher family incomes, in and of themselves, are a panacea for solving the problems associated with youths' delinquent behavior. This is broadly consistent with Painter and Levine (2004) who find that lower income explains the disadvantaged associated with growing up in a single-parent home, but that neither gaps in income nor in parental involvement explain the disadvantages associated with stepfamilies. At the same time, Walker and Zhu (2007) find that the negative effects of parental separation on children's education is largely explained by the reduction in income associated with parents separating. Thus, it may be the case that the income shocks associated with changes in family structure, i.e. parental separation, have negative effects which dissipate over time as families stabilize. Still, Add Health data do not permit us to separately identify the portion of total household income that comes from residential and non-residential fathers. Nor are we able to measure the direct expenditures that non-residential fathers make on their children. Previous researchers have found that financial support from noncustodial fathers is often a predictor of positive outcomes for children (see White and Gilbreth 2001 for a review). Thus, there is some possibility that income from fathers -- particularly non-residential, biological fathers -- may have some additional effect in reducing delinquent behavior which we are not capturing. 


\section{References}

Abbot-Chapman, J, Denholm, C, and Wyld, C (2008) “Gender Differences in Adolescent Risk Taking: Are They Diminishing?: An Australian Intergenerational Study”, Youth \& Society, 40(1), 131-154.

Aizer, A (2004) "Home Alone: Supervision after School and Child Behavior", Journal of Public Economics, Vol. 88, pp. 1835 - 1848.

Amato, PR and Rivera, F (1999) "Paternal Involvement and Children's Behavior Problems" Journal of Marriage and Family, Vol. 61 (2), May, pp. 375 - 384.

Antecol, H and Bedard, K (2007) "Does Single Parenthood Increase the Probability of Teenage Promiscuity, Substance Abuse, and Crime? Journal of Population Economics Vol. 20, pp. 55 - 71.

Averett, SL, Argys LM, and Rees, DI (2009) "Older Siblings and Adolescent Risky Behavior: Does Parenting Play a Role?" Journal of Population Economics DOI 10.1007/s00148-009-0276-1.

Becker, GS (1968) "Crime and Punishment: An Economic Approach", Journal of Political Economy, Vol. 76, pp. 169 - 217.

Bronte-Tinkew, J, Moore, KA, Capps, RC, and Zaff, J (2006) "The Influence of Father Involvement on Youth Risk Behaviors Among Adolescents: A Comparison of Native-Born and Immigrant Families" Social Science Research, Vol. 35, pp. 181 209.

Bumpass, LL, Raley, RK, and Sweet, JA (1995) "The Changing Character of Stepfamilies: Implications of Cohabitation and Nonmarital Childbearing" Demography, 32(3), pg. 425 - 436.

Centers for Disease Control (CDC) (2010) Understanding Youth Violence: Fact Sheet, Available www.cdc.gov.

Cesur, R, Sabia, JJ and Tekin, E. (2011) "The Psychological Costs of War: Military Combat and Mental Health," NBER Working Paper No.16927, April.

Cooksey, EC and Fondell, MM (1996) "Spending Time with His Kids: Effects of Family Structure on Fathers' and Children's Lives", Journal of Marriage and the Family, Vol. 58(3), August, pp. 693 - 707.

Cobb-Clark, DA and Schurer S (2011) “The Stability of Big-Five Personality Traits,” IZA Discussion Paper No. 5943 August.

Dahl, GB and Moretti, E (2004) "The Demand for Sons: Evidence from Divorce, Fertility, and Shotgun Marriage" NBER working paper, 10281, January. 
Del Boca, D and Ribero, R (2003) "Visitations and Transfers After Divorce" Review of Economics of the Household, Vol. 1, pp. 187 - 204.

Ermisch, J (2008) "Child Support and Non-Resident Fathers' Contact with their Children" Journal of Population Economics, Vol. 21(4), pp. 827 - 853.

Goodwin, V, and Davis, B (2011) "Crime Families: Gender and the Intergenerational Transfer of Criminal Tendencies" Trends \& Issues in Crime and Criminal Justice, No. 414, May, pg. 1 - 6, available: http://www.aic.gov.au.

Harris, K.M., C.T. Halpern, E. Whitsel, J. Hussey, J. Tabor, P. Entzel, and J.R. Udry. 2009. The National Longitudinal Study of Adolescent Health: Research Design [WWW document]. URL: http://www.cpc.unc.edu/projects/addhealth/design.

Harris, KM, Furstenberg FF, Jr. and Marmer, JK (1998) "Paternal Involvement with Adolescents in Intact Families: The Influence of Fathers over the Life Course", Demography, Vol. 35 (2), May, pp. 201 - 216.

Harris, KM and Marmer, JK (1996) "Poverty, Paternal Involvement, and Adolescent Wellbeing" Journal of Family Issues, Vol. 17 (5), September, pp. 614 - 640.

Hofferth, SL (2006) "Residential Father Family Type and Child Well-Being: Investment Versus Selection" Demography, Vol. 43 (1), February, pp. 53 - 77.

Kalil, A, Mogstad, M, Rege, M, and Votruba, M (2010) "Divorced Fathers' Proximity and Children's Long Run Outcomes: Evidence from Norwegian Registry Data" Institute for the Study of Labor (IZA) discussion paper no. 4715, January.

King, V (2006) "The Antecedents and Consequences of Adolescents' Relationships with Stepfathers and Nonresident Fathers" Journal of Marriage and Family, Vol. 68(4), November, pp. 910 - 928.

Lundberg, S (2005) "Sons, Daughters, and Parental Behaviour" Oxford Review of Economic Policy, Vol. 21(3), pp. 340 - 356.

Michael, K, and Ben-Zur, H (2007) "Risk-taking Among Adolescents: Associations with Social \& Affective Factors”, Journal of Adolescence, 30, 17-31.

Mocan, HN and Rees D (2005) "Economic Conditions, Deterrence and Juvenile Crime: Evidence from Micro Data.” American Law and Economics Review, Vol. 7, No. 2, pp. 319-349.

Mocan, HN, and Tekin E (2005) "Drugs and Juvenile Crime: Evidence from a Panel of Siblings and Twins," in Substance Use: Individual Behavior, Social Interactions, Markets, and Politics, Bjorn Lindgren and Michael Grossman (eds.), Amsterdam: Elsevier, 2005; pp. 91-120.

Mocan, HN, and Tekin E (2006) "Guns and Juvenile Crime," Journal of Law and Economics, 49:2, pp. 507-532, October 2006 
Painter, G and Levine, DI (2004) "Daddies, Devotion, and Dollars: How do They Matter for Youth?" The American Journal of Economics and Sociology, Vol. 63 (4), October, pp. $813-850$.

Okumura T and Usui E (2010) “Do Parents’ Social Skills Influence Their Children’s Sociability?” IZA Discussion Paper No. 5324, November.

Rees, D, and Sabia, J (2011). "Forced Intercourse, Mental Health and Human Capital" Working Paper, Department of Economics, University of Colorado - Denver.

Ruhm, CJ (2004) "Parental Employment and Child Cognitive Development", Journal Human Resources, Vol. 39(1), pp. 155-192.

U.S. Census Bureau (2010) Current Population Survey 2009, Annual Social and Economic Supplement, Release date January 2010, Available www.census.gov.

U.S. Department of Justice, (2009) Juvenile Arrests 2008, Juvenile Justice Bulletin, Office of Juvenile Justice and Delinquency Prevention, December, Available www.ojjdp.usdoj.gov.

Ventura, SJ (2009) "Changing Patterns of Nonmarital Childbearing in the United States" NCHS Data Brief No. 18, May, Available www.ndc.gov.

Walker, I and Zhu, Y (2007) "Do Dads Matter? Or is it Just their Money that Matters? Unpicking the Effects of Separation on Educational Outcomes" UCD Geary Institute Discussion Paper Series, June 2007.

Wilder, EI and Watt (2002) "Risky Parental Behavior and Adolescent Sexual Activity at First Coitus", Milbank Quarterly, Vol. 80(3), pp. 481 - 524.

White, L and Gilbreth, JG (2001) "When Children Have Two Fathers: Effects of Relationships with Stepfathers and Noncustodial Fathers on Adolescent Outcomes" Journal of Marriage and Family, Vol. 63(1), February, pp. 155 - 167.

Wooldridge, JM (2003) Introductory Econometrics: A Modern Approach, 2nd Edition, 2003. Thomson Southwestern: Mason, Ohio.

Yuan, AS Vogt, and Hamilton, HA (2006) "Stepfather Involvement and Adolescent WellBeing: Do Mothers and Nonresidential Fathers Matter?" Journal of Family Issues, Vol. 27, pp. 1191 - 1213. 
Table 1: Percentage of Adolescents in Various Family Structures at Wave 1

\begin{tabular}{lrrr}
\hline \hline Family Structure & $\begin{array}{r}\text { Percentage } \\
(\text { Total })\end{array}$ & $\begin{array}{r}\text { Percentage } \\
(\text { Boys })\end{array}$ & $\begin{array}{r}\text { Percentage } \\
\text { (Girls) }\end{array}$ \\
\hline Residential Biological Father & 61.60 & 62.82 & 60.47 \\
Non-residential Biological Father Only & 21.29 & 19.81 & 22.68 \\
No Father & 7.07 & 6.82 & 7.29 \\
Non-residential Biological Father \& Residential Stepfather & 7.25 & 7.36 & 7.15 \\
Residential Stepfather Only & 2.79 & 3.19 & 2.41 \\
& & & \\
Total Sample & 11,295 & 5,452 & 5,813 \\
\hline
\end{tabular}

Note: These results pertain to those adolescents also living with their biological mothers.

Source: Add Health data from Wave 1. 

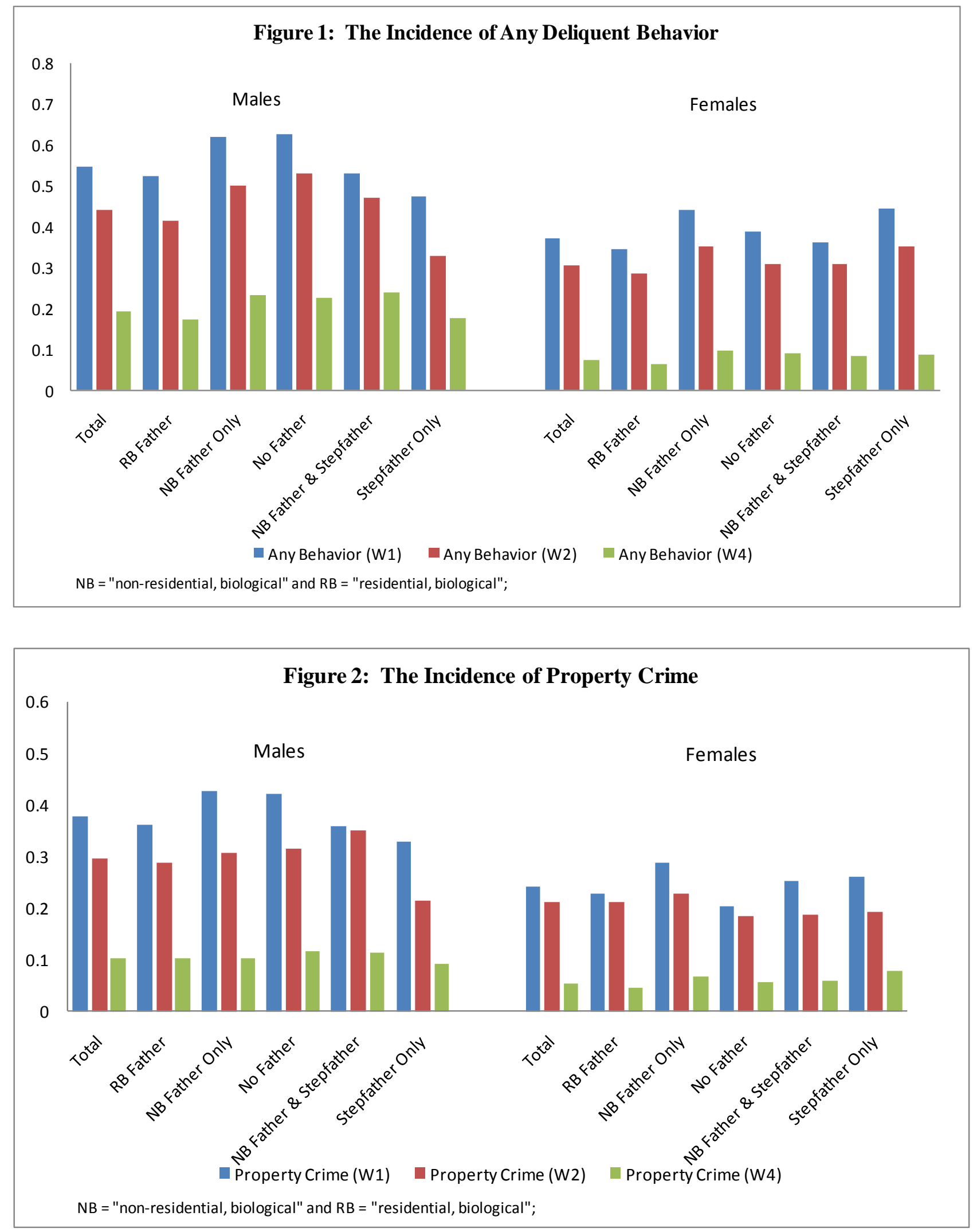

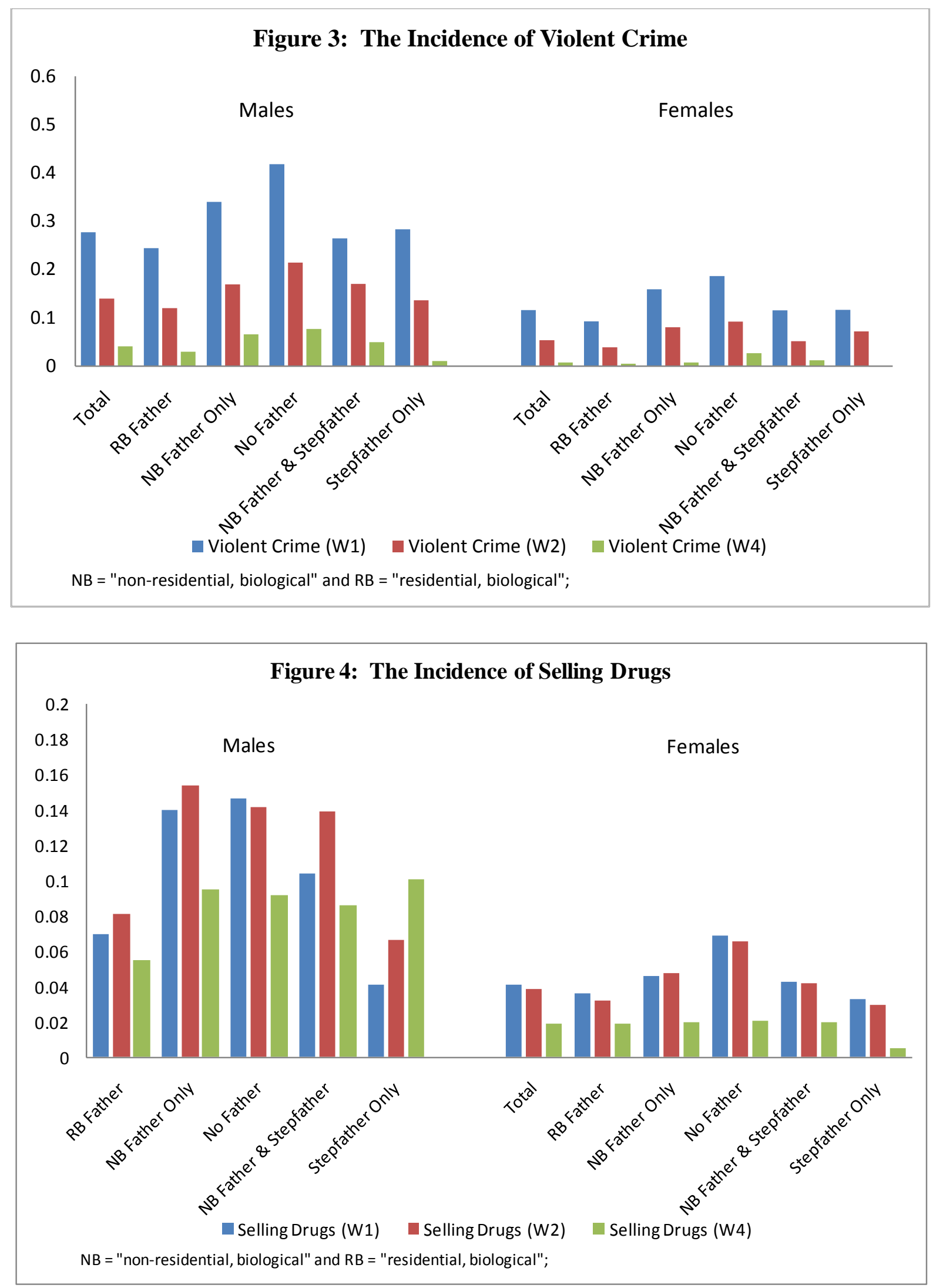


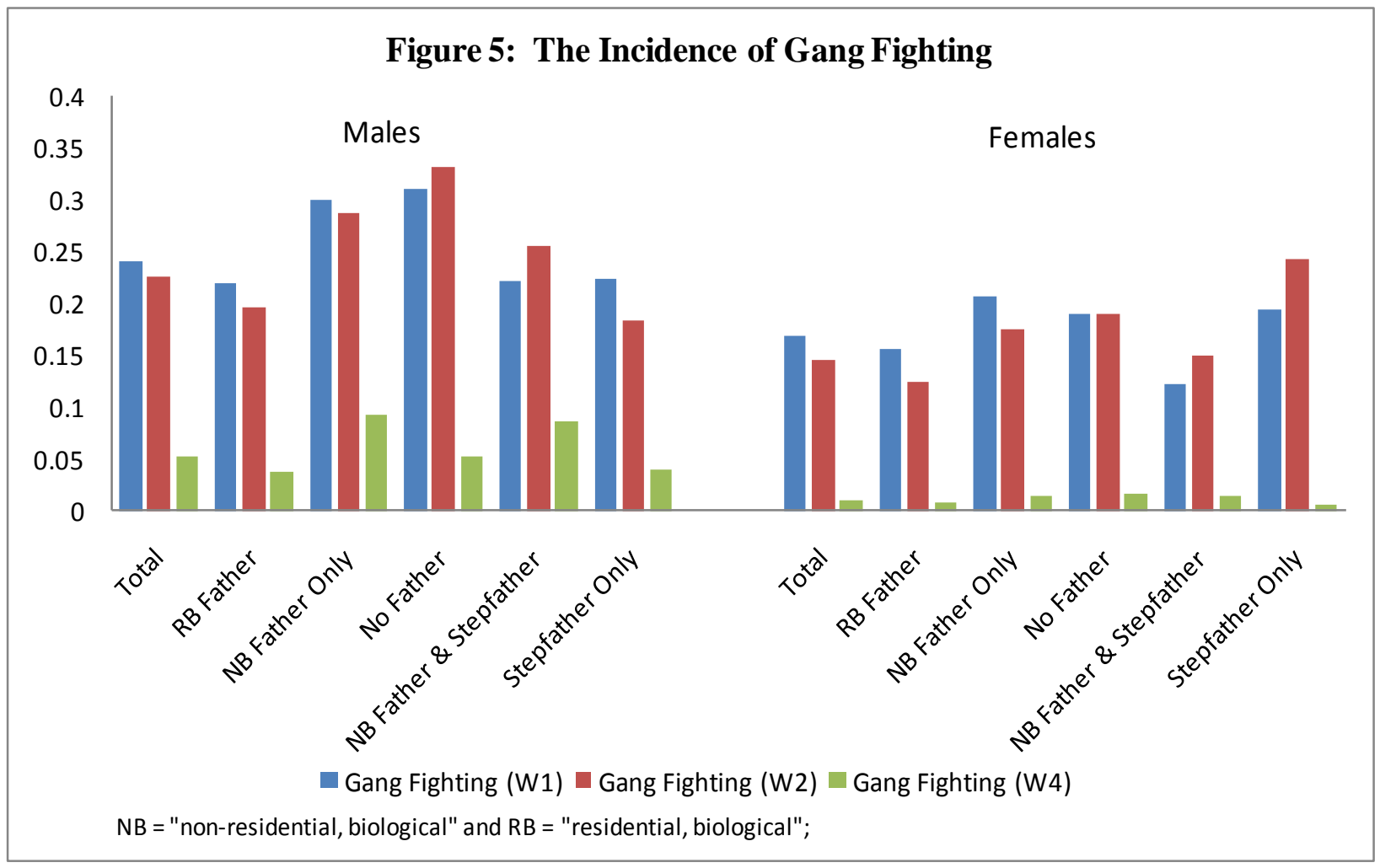


Table 2: Time Spent Doing Things with and Talking to Adolescents (Wave 1) by Family Structure and Gender

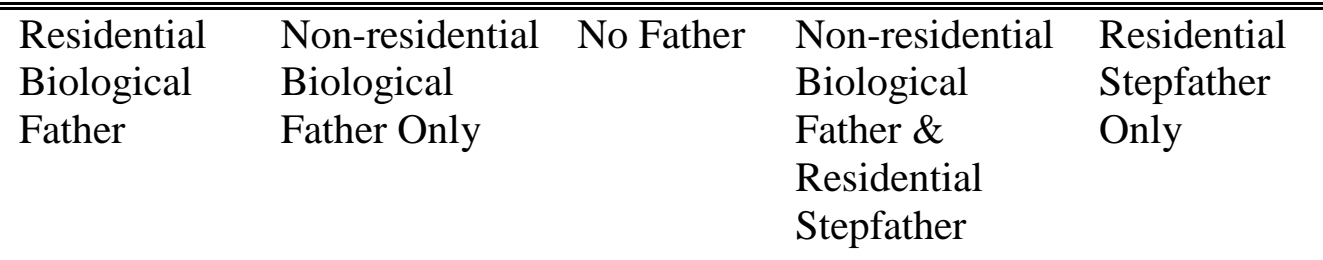

\begin{tabular}{|c|c|c|c|c|c|}
\hline \multicolumn{6}{|l|}{ Boys } \\
\hline Doing things with residential father & 1.54 & --- & --- & $1.08^{\mathrm{a}}$ & $1.11^{\mathrm{a}}$ \\
\hline Doing things with non-residential father & --- & $1.02^{\mathrm{a}}$ & --- & $0.91^{\mathrm{a}, \mathrm{b}}$ & --- \\
\hline Talking to residential father & 1.42 & --- & --- & 1.30 & 1.31 \\
\hline Talking to non-residential father & --- & 1.40 & --- & 1.33 & --- \\
\hline Doing things with mother & 1.68 & $1.53^{\mathrm{a}}$ & $1.42^{\mathrm{a}}$ & $1.48^{\mathrm{a}}$ & 1.52 \\
\hline Talking to mother & 1.69 & $1.94^{\mathrm{a}}$ & 1.60 & $2.05^{\mathrm{a}}$ & 1.69 \\
\hline \multicolumn{6}{|l|}{ Girls } \\
\hline Doing things with residential father & 1.24 & --- & --- & $0.92^{\mathrm{a}}$ & $0.91^{\mathrm{a}}$ \\
\hline Doing things with non-residential father & --- & $0.78^{\mathrm{a}}$ & --- & $0.71^{\mathrm{a}, \mathrm{b}}$ & --- \\
\hline Talking to residential father & 1.38 & --- & --- & 1.34 & 1.19 \\
\hline Talking to non-residential father & --- & $1.49^{\mathrm{a}}$ & --- & 1.48 & --- \\
\hline Doing things with mother & 1.86 & $1.73^{\mathrm{a}}$ & $1.53^{\mathrm{a}}$ & $1.63^{\mathrm{a}}$ & $1.64^{\mathrm{a}}$ \\
\hline Talking to mother & 2.08 & $2.43^{\mathrm{a}}$ & $1.86^{\mathrm{a}}$ & $2.59^{\mathrm{a}}$ & 2.21 \\
\hline
\end{tabular}


Table 3: The Relationship between Father Involvement and Delinquent Behavior among Adolescents - Baseline Model at Wave 2

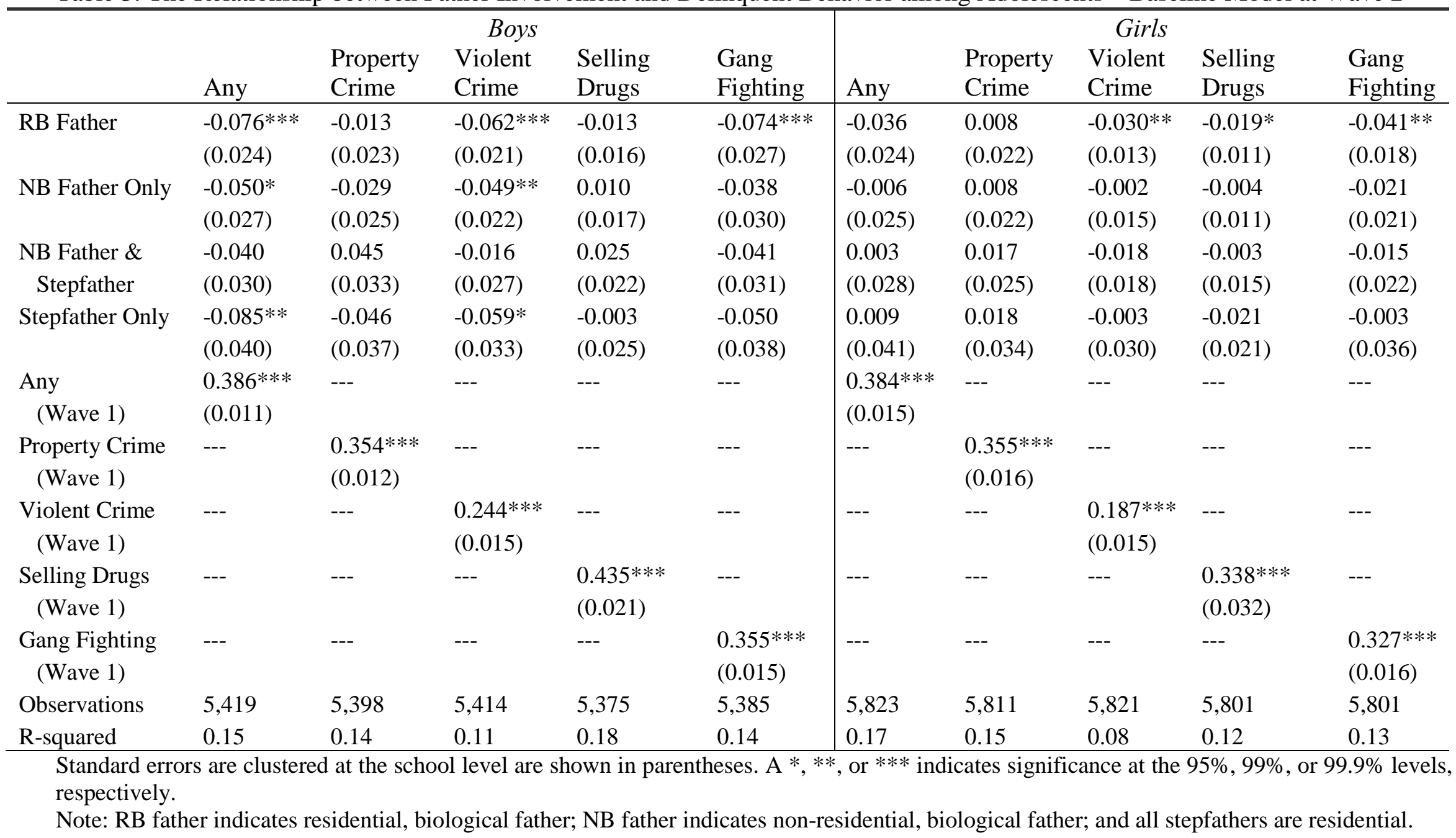


Table 4A: The Relationship between Father Involvement and Delinquent Behavior among Adolescent Boys - Augmented Model at Wave 2

\begin{tabular}{|c|c|c|c|c|c|c|c|c|c|c|}
\hline & Any & Any & $\begin{array}{l}\text { Property } \\
\text { Crime }\end{array}$ & $\begin{array}{l}\text { Property } \\
\text { Crime }\end{array}$ & $\begin{array}{l}\text { Violent } \\
\text { Crime }\end{array}$ & $\begin{array}{l}\text { Violent } \\
\text { Crime }\end{array}$ & $\begin{array}{l}\text { Selling } \\
\text { Drugs }\end{array}$ & $\begin{array}{l}\text { Selling } \\
\text { Drugs }\end{array}$ & $\begin{array}{c}\text { Gang } \\
\text { Fighting }\end{array}$ & $\begin{array}{c}\text { Gang } \\
\text { Fighting }\end{array}$ \\
\hline $\begin{array}{l}\text { NB Father \& } \\
\text { Stepfather }\end{array}$ & $\begin{array}{c}-0.093^{* *} \\
(0.044)\end{array}$ & $\begin{array}{c}-0.104 * * \\
(0.044)\end{array}$ & $\begin{array}{c}-0.011 \\
(0.043)\end{array}$ & $\begin{array}{l}-0.025 \\
(0.044)\end{array}$ & $\begin{array}{c}-0.077 * * \\
(0.036)\end{array}$ & $\begin{array}{c}-0.076^{* *} \\
(0.035)\end{array}$ & $\begin{array}{c}0.013 \\
(0.029)\end{array}$ & $\begin{array}{c}0.003 \\
(0.030)\end{array}$ & $\begin{array}{l}-0.075^{*} \\
(0.042)\end{array}$ & $\begin{array}{l}-0.065 \\
(0.042)\end{array}$ \\
\hline RB Father*Do & $\begin{array}{l}-0.013^{*} \\
(0.007)\end{array}$ & $\begin{array}{l}-0.011 \\
(0.008)\end{array}$ & $\begin{array}{l}-0.000 \\
(0.006)\end{array}$ & $\begin{array}{l}-0.008 \\
(0.007)\end{array}$ & $\begin{array}{c}-0.011^{* *} \\
(0.005)\end{array}$ & $\begin{array}{l}-0.004 \\
(0.006)\end{array}$ & $\begin{array}{c}-0.010 * * * \\
(0.004)\end{array}$ & $\begin{array}{l}-0.001 \\
(0.005)\end{array}$ & $\begin{array}{c}0.001 \\
(0.005)\end{array}$ & $\begin{array}{c}0.003 \\
(0.007)\end{array}$ \\
\hline $\begin{array}{l}\text { NB Father Only } \\
\text { * Do }\end{array}$ & $\begin{array}{c}-0.026^{* *} \\
(0.012)\end{array}$ & $\begin{array}{c}-0.026 * * \\
(0.012)\end{array}$ & $\begin{array}{l}-0.008 \\
(0.010)\end{array}$ & $\begin{array}{l}-0.013 \\
(0.010)\end{array}$ & $\begin{array}{l}-0.005 \\
(0.009)\end{array}$ & $\begin{array}{l}-0.003 \\
(0.009)\end{array}$ & $\begin{array}{l}-0.015 * \\
(0.008)\end{array}$ & $\begin{array}{l}-0.012 \\
(0.008)\end{array}$ & $\begin{array}{l}-0.018^{*} \\
(0.010)\end{array}$ & $\begin{array}{l}-0.019 * \\
(0.010)\end{array}$ \\
\hline $\begin{array}{l}\text { Stepfather* Do } \\
\text { (Dual) }\end{array}$ & $\begin{array}{c}0.009 \\
(0.021)\end{array}$ & $\begin{array}{c}0.015 \\
(0.021)\end{array}$ & $\begin{array}{c}0.015 \\
(0.021)\end{array}$ & $\begin{array}{c}0.016 \\
(0.021)\end{array}$ & $\begin{array}{l}0.034^{* *} \\
(0.014)\end{array}$ & $\begin{array}{c}0.039 * * * \\
(0.014)\end{array}$ & $\begin{array}{c}0.012 \\
(0.014)\end{array}$ & $\begin{array}{c}0.020 \\
(0.014)\end{array}$ & $\begin{array}{c}0.025 \\
(0.019)\end{array}$ & $\begin{array}{c}0.025 \\
(0.019)\end{array}$ \\
\hline $\begin{array}{l}\text { Stepfather Only } \\
\text { *Do }\end{array}$ & $\begin{array}{l}-0.049 \\
(0.035)\end{array}$ & $\begin{array}{l}-0.040 \\
(0.034)\end{array}$ & $\begin{array}{l}-0.004 \\
(0.027)\end{array}$ & $\begin{array}{l}-0.004 \\
(0.026)\end{array}$ & $\begin{array}{l}-0.028 \\
(0.025)\end{array}$ & $\begin{array}{l}-0.020 \\
(0.024)\end{array}$ & $\begin{array}{c}0.000 \\
(0.018)\end{array}$ & $\begin{array}{c}0.012 \\
(0.018)\end{array}$ & $\begin{array}{l}-0.018 \\
(0.023)\end{array}$ & $\begin{array}{l}-0.015 \\
(0.023)\end{array}$ \\
\hline RB Father*Talk & $\begin{array}{l}-0.002 \\
(0.006)\end{array}$ & $\begin{array}{l}-0.004 \\
(0.007)\end{array}$ & $\begin{array}{l}-0.012^{*} \\
(0.007)\end{array}$ & $\begin{array}{l}-0.011 \\
(0.007)\end{array}$ & $\begin{array}{l}-0.002 \\
(0.004)\end{array}$ & $\begin{array}{l}-0.002 \\
(0.005)\end{array}$ & $\begin{array}{c}0.008 * * \\
(0.004)\end{array}$ & $\begin{array}{c}0.008 \\
(0.005)\end{array}$ & $\begin{array}{l}-0.003 \\
(0.006)\end{array}$ & $\begin{array}{l}-0.001 \\
(0.007)\end{array}$ \\
\hline $\begin{array}{l}\text { NB Father Only } \\
\text { *Talk }\end{array}$ & $\begin{array}{c}0.017 \\
(0.012)\end{array}$ & $\begin{array}{c}0.016 \\
(0.012)\end{array}$ & $\begin{array}{c}0.008 \\
(0.010)\end{array}$ & $\begin{array}{c}0.012 \\
(0.010)\end{array}$ & $\begin{array}{l}-0.010 \\
(0.008)\end{array}$ & $\begin{array}{c}-0.011 \\
(0.008)\end{array}$ & $\begin{array}{c}0.015 * * \\
(0.008)\end{array}$ & $\begin{array}{l}0.015^{*} \\
(0.008)\end{array}$ & $\begin{array}{c}0.007 \\
(0.012)\end{array}$ & $\begin{array}{c}0.008 \\
(0.012)\end{array}$ \\
\hline $\begin{array}{l}\text { Stepfather*Talk } \\
\text { (Dual) }\end{array}$ & $\begin{array}{c}0.022 \\
(0.017)\end{array}$ & $\begin{array}{c}0.021 \\
(0.017)\end{array}$ & $\begin{array}{c}0.021 \\
(0.019)\end{array}$ & $\begin{array}{c}0.022 \\
(0.018)\end{array}$ & $\begin{array}{c}0.001 \\
(0.012)\end{array}$ & $\begin{array}{c}0.001 \\
(0.012)\end{array}$ & $\begin{array}{c}0.013 \\
(0.013)\end{array}$ & $\begin{array}{c}0.014 \\
(0.014)\end{array}$ & $\begin{array}{l}-0.026^{*} \\
(0.016)\end{array}$ & $\begin{array}{l}-0.025 \\
(0.016)\end{array}$ \\
\hline $\begin{array}{l}\text { NB Father*Talk } \\
\text { (Dual) }\end{array}$ & $\begin{array}{l}-0.012 \\
(0.020)\end{array}$ & $\begin{array}{l}-0.009 \\
(0.020)\end{array}$ & $\begin{array}{l}-0.018 \\
(0.018)\end{array}$ & $\begin{array}{l}-0.011 \\
(0.018)\end{array}$ & $\begin{array}{c}0.003 \\
(0.015)\end{array}$ & $\begin{array}{c}0.004 \\
(0.015)\end{array}$ & $\begin{array}{l}-0.011 \\
(0.012)\end{array}$ & $\begin{array}{l}-0.011 \\
(0.012)\end{array}$ & $\begin{array}{l}0.027 * \\
(0.015)\end{array}$ & $\begin{array}{l}0.029 * \\
(0.015)\end{array}$ \\
\hline $\begin{array}{l}\text { Stepfather Only } \\
{ }^{*} \text { Talk }\end{array}$ & $\begin{array}{l}-0.012 \\
(0.029)\end{array}$ & $\begin{array}{l}-0.015 \\
(0.029)\end{array}$ & $\begin{array}{l}-0.021 \\
(0.023)\end{array}$ & $\begin{array}{l}-0.020 \\
(0.023)\end{array}$ & $\begin{array}{l}-0.002 \\
(0.017)\end{array}$ & $\begin{array}{l}-0.002 \\
(0.017)\end{array}$ & $\begin{array}{l}-0.021 \\
(0.014)\end{array}$ & $\begin{array}{l}-0.020 \\
(0.014)\end{array}$ & $\begin{array}{c}0.006 \\
(0.023)\end{array}$ & $\begin{array}{c}0.006 \\
(0.023)\end{array}$ \\
\hline
\end{tabular}




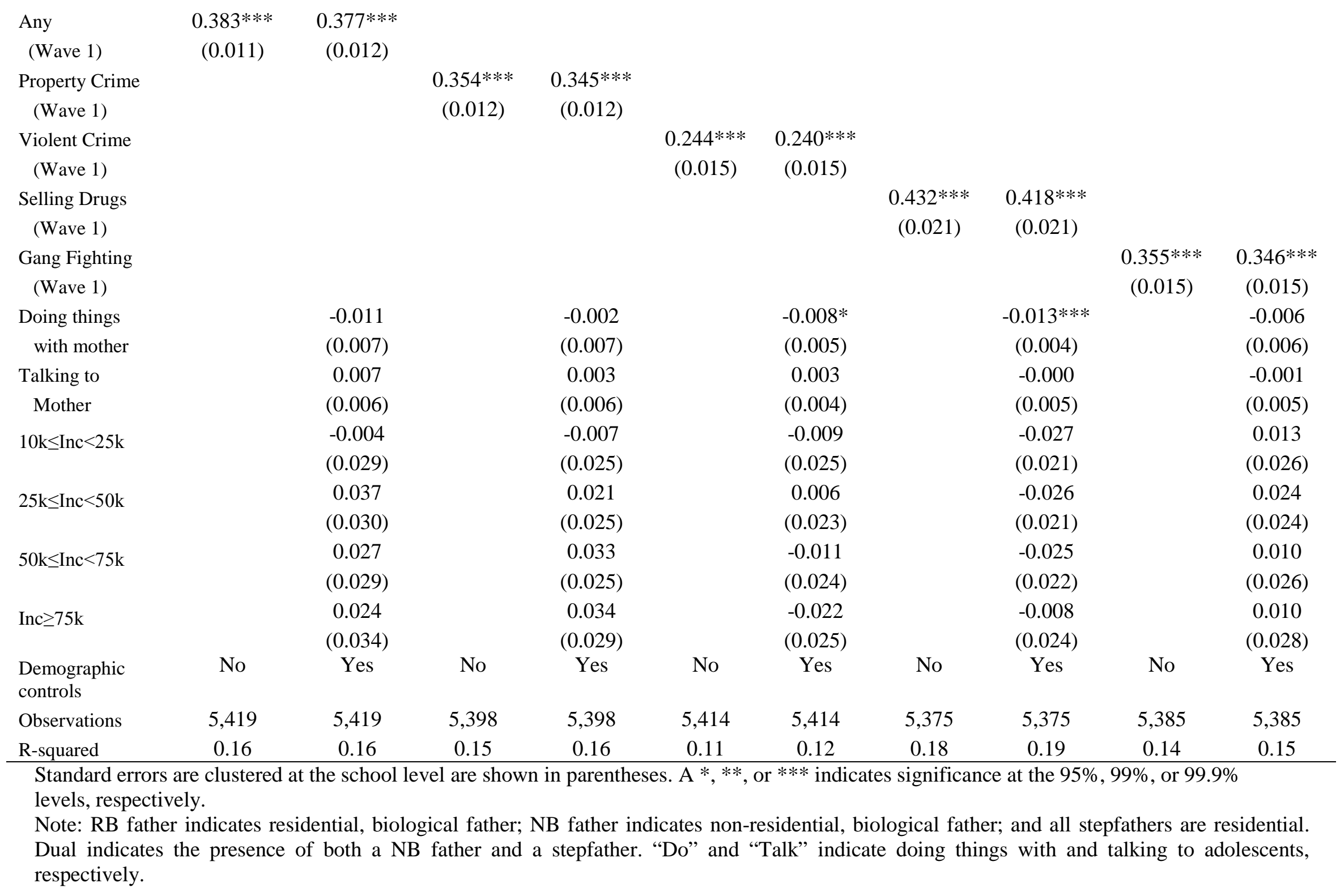


Table 4B: The Relationship between Father Involvement and Delinquent Behavior among Adolescent Girls - Augmented Model at Wave 2

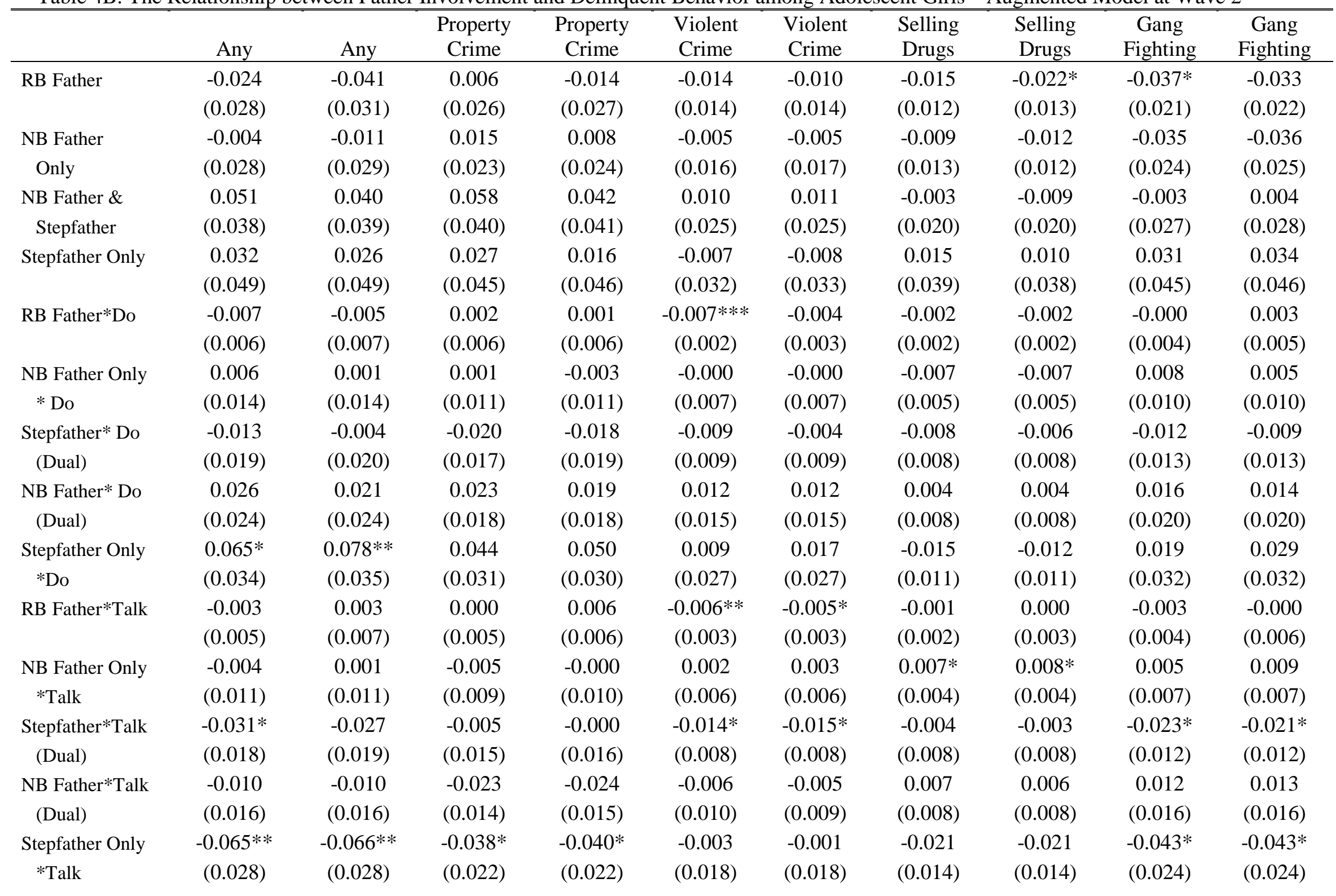




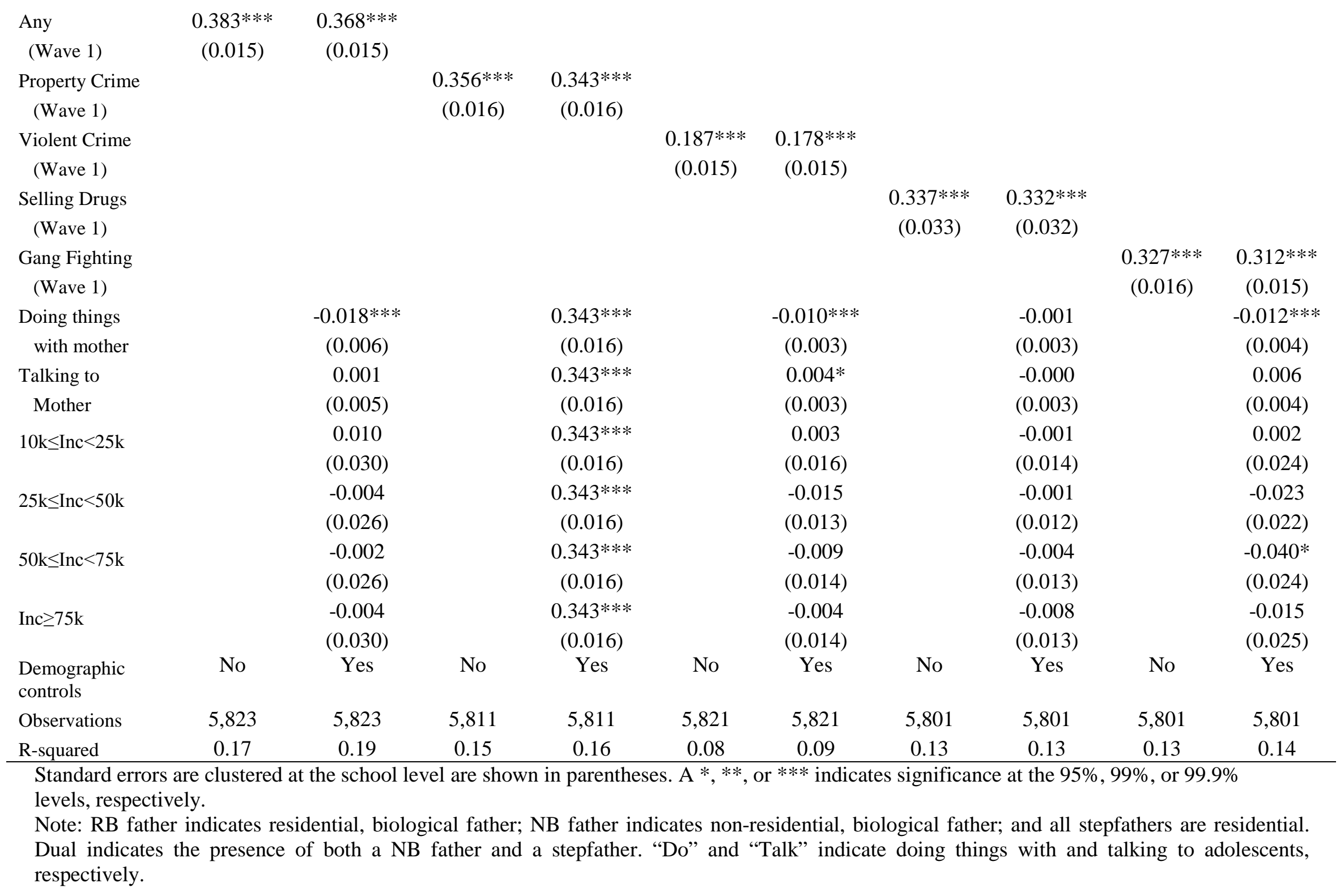


Table 5: The Relationship between Father Involvement and Delinquent Behavior among Young Adults - Baseline Model at Wave 4

\begin{tabular}{|c|c|c|c|c|c|c|c|c|c|c|}
\hline & \multicolumn{5}{|c|}{ Men } & \multicolumn{5}{|c|}{ Women } \\
\hline RB Father & $\begin{array}{c}-0.051^{* *} \\
(0.022)\end{array}$ & $\begin{array}{l}-0.022 \\
(0.018)\end{array}$ & $\begin{array}{c}-0.041^{* * *} \\
(0.014)\end{array}$ & $\begin{array}{c}-0.035^{* * *} \\
(0.012)\end{array}$ & $\begin{array}{c}-0.029 * * \\
(0.013)\end{array}$ & $\begin{array}{l}-0.018 \\
(0.013)\end{array}$ & $\begin{array}{l}-0.009 \\
(0.011)\end{array}$ & $\begin{array}{l}-0.006 \\
(0.005)\end{array}$ & $\begin{array}{l}-0.005 \\
(0.006)\end{array}$ & $\begin{array}{l}-0.004 \\
(0.005)\end{array}$ \\
\hline NB Father Only & $\begin{array}{l}-0.025 \\
(0.025)\end{array}$ & $\begin{array}{l}-0.027 \\
(0.019)\end{array}$ & $\begin{array}{l}-0.021 \\
(0.015)\end{array}$ & $\begin{array}{l}-0.006 \\
(0.015)\end{array}$ & $\begin{array}{l}-0.001 \\
(0.016)\end{array}$ & $\begin{array}{c}0.011 \\
(0.014)\end{array}$ & $\begin{array}{c}0.011 \\
(0.012)\end{array}$ & $\begin{array}{l}-0.004 \\
(0.005)\end{array}$ & $\begin{array}{c}0.000 \\
(0.007)\end{array}$ & $\begin{array}{c}0.003 \\
(0.006)\end{array}$ \\
\hline $\begin{array}{c}\text { NB Father \& } \\
\text { Stepfather }\end{array}$ & $\begin{array}{l}-0.007 \\
(0.028)\end{array}$ & $\begin{array}{l}-0.022 \\
(0.024)\end{array}$ & $\begin{array}{c}-0.031^{* *} \\
(0.014)\end{array}$ & $\begin{array}{c}0.002 \\
(0.018)\end{array}$ & $\begin{array}{c}0.002 \\
(0.017)\end{array}$ & $\begin{array}{l}-0.012 \\
(0.018)\end{array}$ & $\begin{array}{l}-0.008 \\
(0.015)\end{array}$ & $\begin{array}{c}0.001 \\
(0.007)\end{array}$ & $\begin{array}{c}0.001 \\
(0.009)\end{array}$ & $\begin{array}{c}0.010 \\
(0.008)\end{array}$ \\
\hline Stepfather Only & $\begin{array}{c}0.001 \\
(0.038)\end{array}$ & $\begin{array}{c}0.002 \\
(0.033)\end{array}$ & $\begin{array}{c}-0.040^{* *} \\
(0.020)\end{array}$ & $\begin{array}{c}0.042 \\
(0.030)\end{array}$ & $\begin{array}{l}-0.011 \\
(0.023)\end{array}$ & $\begin{array}{l}-0.002 \\
(0.026)\end{array}$ & $\begin{array}{c}0.010 \\
(0.022)\end{array}$ & $\begin{array}{c}-0.012^{* *} \\
(0.005)\end{array}$ & $\begin{array}{l}-0.009 \\
(0.010)\end{array}$ & $\begin{array}{l}-0.000 \\
(0.010)\end{array}$ \\
\hline $\begin{array}{l}\text { Any } \\
\text { (Wave 1) }\end{array}$ & $\begin{array}{c}0.105^{* * *} \\
(0.010)\end{array}$ & & & & & $\begin{array}{c}0.060 * * * \\
(0.007)\end{array}$ & & & & \\
\hline $\begin{array}{l}\text { Property Crime } \\
\text { (Wave 1) }\end{array}$ & & $\begin{array}{c}0.077 * * * \\
(0.009)\end{array}$ & & & & & $\begin{array}{c}0.055^{* * * *} \\
(0.007)\end{array}$ & & & \\
\hline $\begin{array}{l}\text { Gang Fight } \\
\text { (Wave 1) }\end{array}$ & & & & & $\begin{array}{c}0.058 * * * \\
(0.007)\end{array}$ & & & & & $\begin{array}{c}0.021 * * * \\
(0.005)\end{array}$ \\
\hline Observations & 5,866 & 5,865 & 5,857 & 5,846 & 5,851 & 6,741 & 6,741 & 6,736 & 6,732 & 6,731 \\
\hline R-squared & 0.02 & 0.02 & 0.02 & 0.02 & 0.02 & 0.02 & 0.01 & 0.00 & 0.01 & 0.01 \\
\hline
\end{tabular}


Table 6A: The Relationship between Father Involvement and Delinquent Behavior among Young Men - Augmented Model at Wave 4

\begin{tabular}{|c|c|c|c|c|c|c|c|c|c|c|}
\hline & Any & Any & $\begin{array}{c}\text { Property } \\
\text { Crime }\end{array}$ & $\begin{array}{c}\text { Property } \\
\text { Crime }\end{array}$ & $\begin{array}{l}\text { Violent } \\
\text { Crime }\end{array}$ & $\begin{array}{l}\text { Violent } \\
\text { Crime } \\
\end{array}$ & $\begin{array}{l}\text { Selling } \\
\text { Drugs }\end{array}$ & $\begin{array}{l}\text { Selling } \\
\text { Drugs }\end{array}$ & $\begin{array}{c}\text { Gang } \\
\text { Fighting }\end{array}$ & $\begin{array}{c}\text { Gang } \\
\text { Fighting }\end{array}$ \\
\hline RB Father & $\begin{array}{c}-0.052 * * \\
(0.023)\end{array}$ & $\begin{array}{l}-0.040 \\
(0.024)\end{array}$ & $\begin{array}{l}-0.030 \\
(0.020)\end{array}$ & $\begin{array}{l}-0.024 \\
(0.020)\end{array}$ & $\begin{array}{c}-0.043^{* * *} \\
(0.015)\end{array}$ & $\begin{array}{c}-0.035^{* *} \\
(0.017)\end{array}$ & $\begin{array}{c}-0.030 * * \\
(0.014)\end{array}$ & $\begin{array}{l}-0.021 \\
(0.014)\end{array}$ & $\begin{array}{c}-0.028 * * \\
(0.014)\end{array}$ & $\begin{array}{l}-0.022 \\
(0.015)\end{array}$ \\
\hline $\begin{array}{l}\text { NB Father } \\
\text { Only }\end{array}$ & $\begin{array}{l}-0.048 * \\
(0.028)\end{array}$ & $\begin{array}{l}-0.049 * \\
(0.029)\end{array}$ & $\begin{array}{l}-0.037 * \\
(0.021)\end{array}$ & $\begin{array}{l}-0.037 * \\
(0.021)\end{array}$ & $\begin{array}{l}-0.023 \\
(0.017)\end{array}$ & $\begin{array}{l}-0.023 \\
(0.017)\end{array}$ & $\begin{array}{l}-0.023 \\
(0.017)\end{array}$ & $\begin{array}{l}-0.025 \\
(0.017)\end{array}$ & $\begin{array}{l}-0.004 \\
(0.018)\end{array}$ & $\begin{array}{l}-0.004 \\
(0.018)\end{array}$ \\
\hline $\begin{array}{l}\text { NB Father \& } \\
\text { Stepfather }\end{array}$ & $\begin{array}{l}-0.005 \\
(0.042)\end{array}$ & $\begin{array}{c}0.001 \\
(0.043)\end{array}$ & $\begin{array}{l}-0.010 \\
(0.032)\end{array}$ & $\begin{array}{l}-0.007 \\
(0.033)\end{array}$ & $\begin{array}{l}-0.031 \\
(0.023)\end{array}$ & $\begin{array}{l}-0.023 \\
(0.024)\end{array}$ & $\begin{array}{l}-0.026 \\
(0.026)\end{array}$ & $\begin{array}{l}-0.023 \\
(0.028)\end{array}$ & $\begin{array}{l}-0.013 \\
(0.024)\end{array}$ & $\begin{array}{l}-0.006 \\
(0.025)\end{array}$ \\
\hline Stepfather Only & $\begin{array}{l}-0.028 \\
(0.047)\end{array}$ & $\begin{array}{l}-0.029 \\
(0.046)\end{array}$ & $\begin{array}{l}-0.018 \\
(0.035)\end{array}$ & $\begin{array}{l}-0.020 \\
(0.034)\end{array}$ & $\begin{array}{c}-0.056 * * \\
(0.022)\end{array}$ & $\begin{array}{c}-0.054^{* *} \\
(0.023)\end{array}$ & $\begin{array}{c}0.020 \\
(0.038)\end{array}$ & $\begin{array}{c}0.021 \\
(0.039)\end{array}$ & $\begin{array}{l}-0.030 \\
(0.027)\end{array}$ & $\begin{array}{l}-0.030 \\
(0.026)\end{array}$ \\
\hline RB Father*Do & $\begin{array}{c}0.003 \\
(0.005)\end{array}$ & $\begin{array}{l}-0.000 \\
(0.006)\end{array}$ & $\begin{array}{c}0.005 \\
(0.004)\end{array}$ & $\begin{array}{c}0.003 \\
(0.005)\end{array}$ & $\begin{array}{c}0.001 \\
(0.003)\end{array}$ & $\begin{array}{l}-0.000 \\
(0.003)\end{array}$ & $\begin{array}{l}-0.000 \\
(0.003)\end{array}$ & $\begin{array}{l}-0.003 \\
(0.004)\end{array}$ & $\begin{array}{l}-0.001 \\
(0.003)\end{array}$ & $\begin{array}{l}-0.001 \\
(0.003)\end{array}$ \\
\hline $\begin{array}{l}\text { NB Father Only } \\
\text { * Do }\end{array}$ & $\begin{array}{l}-0.003 \\
(0.010)\end{array}$ & $\begin{array}{l}-0.008 \\
(0.010)\end{array}$ & $\begin{array}{l}-0.000 \\
(0.008)\end{array}$ & $\begin{array}{l}-0.004 \\
(0.008)\end{array}$ & $\begin{array}{l}-0.006 \\
(0.006)\end{array}$ & $\begin{array}{l}-0.007 \\
(0.006)\end{array}$ & $\begin{array}{c}0.001 \\
(0.007)\end{array}$ & $\begin{array}{l}-0.002 \\
(0.007)\end{array}$ & $\begin{array}{l}-0.004 \\
(0.007)\end{array}$ & $\begin{array}{l}-0.005 \\
(0.007)\end{array}$ \\
\hline $\begin{array}{l}\text { Stepfather* Do } \\
\text { (Dual) }\end{array}$ & $\begin{array}{l}0.038^{*} \\
(0.021)\end{array}$ & $\begin{array}{l}0.038 * \\
(0.021)\end{array}$ & $\begin{array}{l}-0.003 \\
(0.013)\end{array}$ & $\begin{array}{l}-0.004 \\
(0.013)\end{array}$ & $\begin{array}{c}0.003 \\
(0.012)\end{array}$ & $\begin{array}{c}0.001 \\
(0.012)\end{array}$ & $\begin{array}{c}0.015 \\
(0.015)\end{array}$ & $\begin{array}{c}0.014 \\
(0.015)\end{array}$ & $\begin{array}{c}0.043^{* * *} \\
(0.016)\end{array}$ & $\begin{array}{c}0.044^{* * *} \\
(0.016)\end{array}$ \\
\hline $\begin{array}{l}\text { NB Father* Do } \\
\text { (Dual) }\end{array}$ & $\begin{array}{l}-0.005 \\
(0.016)\end{array}$ & $\begin{array}{l}-0.010 \\
(0.017)\end{array}$ & $\begin{array}{l}-0.017 \\
(0.012)\end{array}$ & $\begin{array}{l}-0.020 \\
(0.012)\end{array}$ & $\begin{array}{c}0.007 \\
(0.009)\end{array}$ & $\begin{array}{c}0.007 \\
(0.009)\end{array}$ & $\begin{array}{l}-0.000 \\
(0.014)\end{array}$ & $\begin{array}{l}-0.003 \\
(0.014)\end{array}$ & $\begin{array}{l}-0.005 \\
(0.010)\end{array}$ & $\begin{array}{l}-0.005 \\
(0.010)\end{array}$ \\
\hline $\begin{array}{l}\text { Stepfather Only } \\
\text { *Do }\end{array}$ & $\begin{array}{l}-0.020 \\
(0.027)\end{array}$ & $\begin{array}{l}-0.017 \\
(0.027)\end{array}$ & $\begin{array}{l}-0.022 \\
(0.017)\end{array}$ & $\begin{array}{l}-0.021 \\
(0.017)\end{array}$ & $\begin{array}{l}-0.010 \\
(0.009)\end{array}$ & $\begin{array}{l}-0.012 \\
(0.009)\end{array}$ & $\begin{array}{l}-0.005 \\
(0.024)\end{array}$ & $\begin{array}{l}-0.007 \\
(0.025)\end{array}$ & $\begin{array}{l}-0.001 \\
(0.016)\end{array}$ & $\begin{array}{c}0.001 \\
(0.016)\end{array}$ \\
\hline RB Father*Talk & $\begin{array}{l}-0.002 \\
(0.006)\end{array}$ & $\begin{array}{c}0.003 \\
(0.006)\end{array}$ & $\begin{array}{c}0.000 \\
(0.004)\end{array}$ & $\begin{array}{c}0.003 \\
(0.005)\end{array}$ & $\begin{array}{l}-0.001 \\
(0.002)\end{array}$ & $\begin{array}{c}0.001 \\
(0.003)\end{array}$ & $\begin{array}{l}-0.003 \\
(0.003)\end{array}$ & $\begin{array}{c}0.001 \\
(0.004)\end{array}$ & $\begin{array}{c}0.000 \\
(0.003)\end{array}$ & $\begin{array}{c}0.002 \\
(0.003)\end{array}$ \\
\hline $\begin{array}{l}\text { NB Father Only } \\
\text { *Talk }\end{array}$ & $\begin{array}{l}0.016^{*} \\
(0.009)\end{array}$ & $\begin{array}{l}0.022 * * \\
(0.009)\end{array}$ & $\begin{array}{c}0.007 \\
(0.006)\end{array}$ & $\begin{array}{l}0.011^{*} \\
(0.006)\end{array}$ & $\begin{array}{c}0.005 \\
(0.006)\end{array}$ & $\begin{array}{c}0.006 \\
(0.006)\end{array}$ & $\begin{array}{c}0.010 \\
(0.007)\end{array}$ & $\begin{array}{c}0.014^{* *} \\
(0.007)\end{array}$ & $\begin{array}{c}0.005 \\
(0.007)\end{array}$ & $\begin{array}{c}0.006 \\
(0.007)\end{array}$ \\
\hline $\begin{array}{l}\text { Stepfather*Talk } \\
\text { (Dual) }\end{array}$ & $\begin{array}{c}0.001 \\
(0.016)\end{array}$ & $\begin{array}{c}0.004 \\
(0.016)\end{array}$ & $\begin{array}{c}0.005 \\
(0.012)\end{array}$ & $\begin{array}{c}0.009 \\
(0.013)\end{array}$ & $\begin{array}{c}0.009 \\
(0.010)\end{array}$ & $\begin{array}{c}0.010 \\
(0.010)\end{array}$ & $\begin{array}{c}0.011 \\
(0.011)\end{array}$ & $\begin{array}{c}0.013 \\
(0.010)\end{array}$ & $\begin{array}{l}-0.006 \\
(0.012)\end{array}$ & $\begin{array}{l}-0.005 \\
(0.012)\end{array}$ \\
\hline $\begin{array}{l}\text { NB Father*Talk } \\
\text { (Dual) }\end{array}$ & $\begin{array}{l}-0.028 \\
(0.018)\end{array}$ & $\begin{array}{l}-0.024 \\
(0.018)\end{array}$ & $\begin{array}{l}-0.002 \\
(0.013)\end{array}$ & $\begin{array}{c}0.000 \\
(0.012)\end{array}$ & $\begin{array}{c}-0.016 * * \\
(0.007)\end{array}$ & $\begin{array}{c}-0.015^{* *} \\
(0.007)\end{array}$ & $\begin{array}{l}-0.002 \\
(0.013)\end{array}$ & $\begin{array}{c}0.000 \\
(0.012)\end{array}$ & $\begin{array}{l}-0.014 \\
(0.010)\end{array}$ & $\begin{array}{l}-0.013 \\
(0.010)\end{array}$ \\
\hline $\begin{array}{l}\text { Stepfather Only } \\
\quad \text { *Talk }\end{array}$ & $\begin{array}{c}0.040 \\
(0.028)\end{array}$ & $\begin{array}{c}0.043 \\
(0.027)\end{array}$ & $\begin{array}{l}0.035^{*} \\
(0.020)\end{array}$ & $\begin{array}{l}0.039^{*} \\
(0.020)\end{array}$ & $\begin{array}{c}0.022 \\
(0.014)\end{array}$ & $\begin{array}{l}0.024^{*} \\
(0.014)\end{array}$ & $\begin{array}{c}0.022 \\
(0.023)\end{array}$ & $\begin{array}{c}0.025 \\
(0.022)\end{array}$ & $\begin{array}{c}0.015 \\
(0.017)\end{array}$ & $\begin{array}{c}0.016 \\
(0.017)\end{array}$ \\
\hline
\end{tabular}




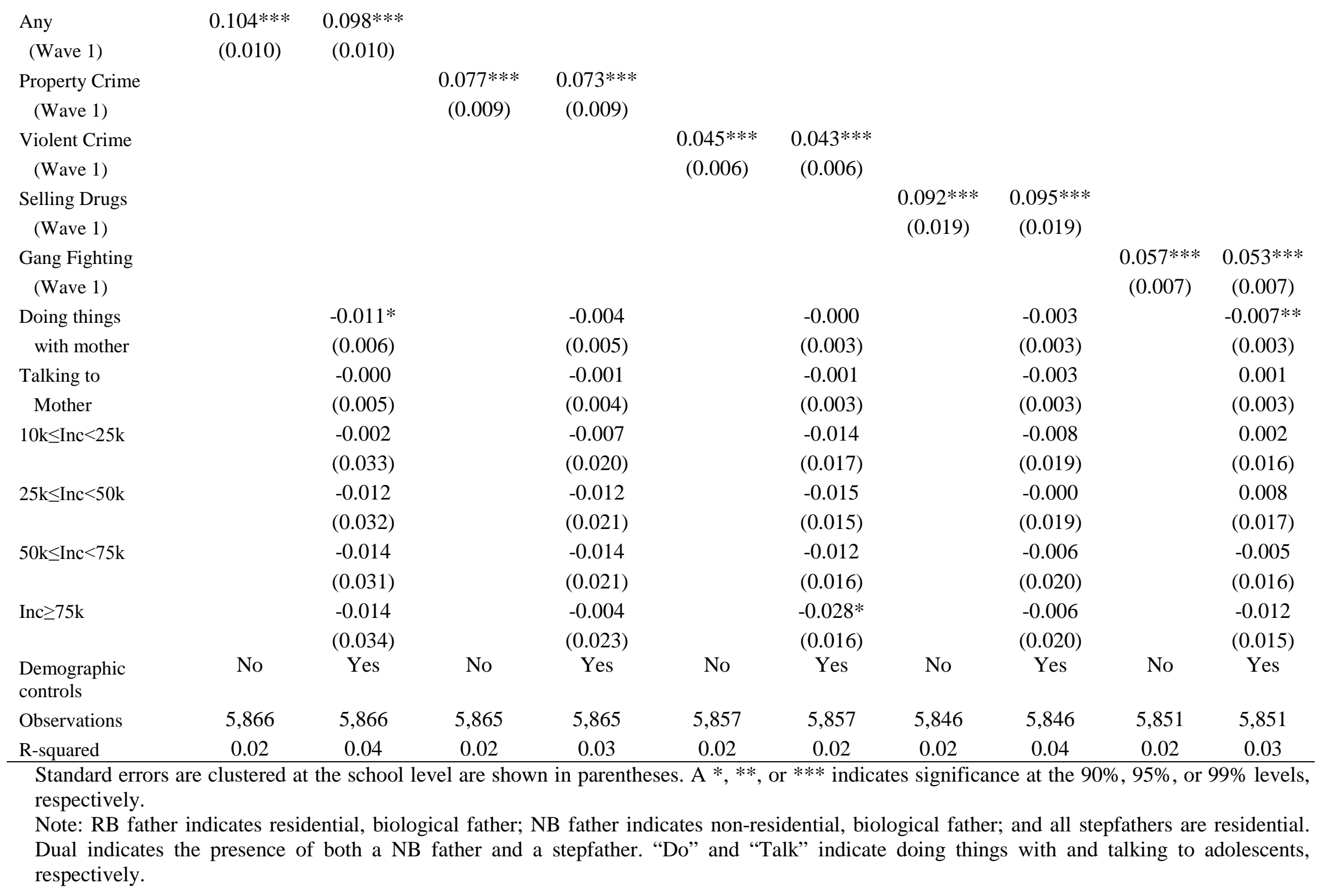


Table 6B: The Relationship between Father Involvement and Delinquent Behavior among Young Women - Augmented Model at Wave 4

\begin{tabular}{|c|c|c|c|c|c|c|c|c|c|c|}
\hline & Any & Any & $\begin{array}{c}\text { Property } \\
\text { Crime }\end{array}$ & $\begin{array}{c}\text { Property } \\
\text { Crime }\end{array}$ & $\begin{array}{l}\text { Violent } \\
\text { Crime }\end{array}$ & $\begin{array}{l}\text { Violent } \\
\text { Crime }\end{array}$ & $\begin{array}{l}\text { Selling } \\
\text { Drugs }\end{array}$ & $\begin{array}{l}\text { Selling } \\
\text { Drugs }\end{array}$ & $\begin{array}{c}\text { Gang } \\
\text { Fighting }\end{array}$ & $\begin{array}{c}\text { Gang } \\
\text { Fighting }\end{array}$ \\
\hline RB Father & $\begin{array}{l}-0.000 \\
(0.014)\end{array}$ & $\begin{array}{c}0.011 \\
(0.016)\end{array}$ & $\begin{array}{c}0.002 \\
(0.013)\end{array}$ & $\begin{array}{c}0.011 \\
(0.014)\end{array}$ & $\begin{array}{l}-0.001 \\
(0.006)\end{array}$ & $\begin{array}{c}0.001 \\
(0.006)\end{array}$ & $\begin{array}{c}0.002 \\
(0.007)\end{array}$ & $\begin{array}{c}0.004 \\
(0.007)\end{array}$ & $\begin{array}{l}-0.001 \\
(0.006)\end{array}$ & $\begin{array}{c}0.000 \\
(0.006)\end{array}$ \\
\hline $\begin{array}{l}\text { NB Father } \\
\text { Only }\end{array}$ & $\begin{array}{c}0.003 \\
(0.017)\end{array}$ & $\begin{array}{l}-0.000 \\
(0.016)\end{array}$ & $\begin{array}{l}-0.001 \\
(0.014)\end{array}$ & $\begin{array}{l}-0.003 \\
(0.014)\end{array}$ & $\begin{array}{l}-0.003 \\
(0.005)\end{array}$ & $\begin{array}{l}-0.003 \\
(0.005)\end{array}$ & $\begin{array}{c}0.004 \\
(0.008)\end{array}$ & $\begin{array}{c}0.001 \\
(0.008)\end{array}$ & $\begin{array}{c}0.001 \\
(0.007)\end{array}$ & $\begin{array}{c}0.002 \\
(0.007)\end{array}$ \\
\hline $\begin{array}{l}\text { NB Father \& } \\
\text { Stepfather }\end{array}$ & $\begin{array}{c}0.006 \\
(0.023)\end{array}$ & $\begin{array}{c}0.008 \\
(0.023)\end{array}$ & $\begin{array}{c}0.003 \\
(0.019)\end{array}$ & $\begin{array}{c}0.004 \\
(0.019)\end{array}$ & $\begin{array}{l}-0.007 \\
(0.008)\end{array}$ & $\begin{array}{l}-0.006 \\
(0.008)\end{array}$ & $\begin{array}{c}0.001 \\
(0.013)\end{array}$ & $\begin{array}{l}-0.000 \\
(0.013)\end{array}$ & $\begin{array}{c}0.017 \\
(0.011)\end{array}$ & $\begin{array}{l}0.020^{*} \\
(0.011)\end{array}$ \\
\hline Stepfather Only & $\begin{array}{c}0.013 \\
(0.039)\end{array}$ & $\begin{array}{c}0.017 \\
(0.039)\end{array}$ & $\begin{array}{c}0.009 \\
(0.035)\end{array}$ & $\begin{array}{c}0.010 \\
(0.035)\end{array}$ & $\begin{array}{c}-0.012 * * \\
(0.005)\end{array}$ & $\begin{array}{l}-0.010^{*} \\
(0.005)\end{array}$ & $\begin{array}{l}-0.001 \\
(0.015)\end{array}$ & $\begin{array}{l}-0.002 \\
(0.014)\end{array}$ & $\begin{array}{c}0.017 \\
(0.021)\end{array}$ & $\begin{array}{c}0.018 \\
(0.020)\end{array}$ \\
\hline RB Father*Do & $\begin{array}{c}-0.010^{* * *} \\
(0.003)\end{array}$ & $\begin{array}{c}-0.008^{* *} \\
(0.004)\end{array}$ & $\begin{array}{c}-0.006^{* *} \\
(0.003)\end{array}$ & $\begin{array}{l}-0.005 \\
(0.003)\end{array}$ & $\begin{array}{c}-0.002^{* * *} \\
(0.001)\end{array}$ & $\begin{array}{l}-0.002 * \\
(0.001)\end{array}$ & $\begin{array}{c}-0.004^{* *} \\
(0.002)\end{array}$ & $\begin{array}{c}-0.004^{* *} \\
(0.002)\end{array}$ & $\begin{array}{l}-0.001 \\
(0.001)\end{array}$ & $\begin{array}{l}-0.000 \\
(0.001)\end{array}$ \\
\hline $\begin{array}{l}\text { NB Father Only } \\
\text { * Do }\end{array}$ & $\begin{array}{l}0.012 * \\
(0.007)\end{array}$ & $\begin{array}{c}0.011 * \\
(0.007)\end{array}$ & $\begin{array}{l}0.011^{*} \\
(0.006)\end{array}$ & $\begin{array}{l}0.011^{*} \\
(0.006)\end{array}$ & $\begin{array}{c}0.001 \\
(0.003)\end{array}$ & $\begin{array}{c}0.001 \\
(0.003)\end{array}$ & $\begin{array}{c}0.001 \\
(0.003)\end{array}$ & $\begin{array}{c}0.001 \\
(0.003)\end{array}$ & $\begin{array}{c}0.003 \\
(0.003)\end{array}$ & $\begin{array}{c}0.003 \\
(0.003)\end{array}$ \\
\hline $\begin{array}{l}\text { Stepfather* Do } \\
\text { (Dual) }\end{array}$ & $\begin{array}{l}-0.012 \\
(0.008)\end{array}$ & $\begin{array}{l}-0.009 \\
(0.009)\end{array}$ & $\begin{array}{l}-0.009 * \\
(0.005)\end{array}$ & $\begin{array}{l}-0.006 \\
(0.006)\end{array}$ & $\begin{array}{c}0.001 \\
(0.004)\end{array}$ & $\begin{array}{c}0.001 \\
(0.005)\end{array}$ & $\begin{array}{c}0.001 \\
(0.007)\end{array}$ & $\begin{array}{c}0.002 \\
(0.007)\end{array}$ & $\begin{array}{c}-0.010 * * \\
(0.005)\end{array}$ & $\begin{array}{c}-0.010 * * \\
(0.005)\end{array}$ \\
\hline $\begin{array}{l}\text { NB Father* Do } \\
\text { (Dual) }\end{array}$ & $\begin{array}{c}0.005 \\
(0.009)\end{array}$ & $\begin{array}{c}0.005 \\
(0.010)\end{array}$ & $\begin{array}{c}0.004 \\
(0.007)\end{array}$ & $\begin{array}{c}0.005 \\
(0.007)\end{array}$ & $\begin{array}{c}0.003 \\
(0.006)\end{array}$ & $\begin{array}{c}0.003 \\
(0.006)\end{array}$ & $\begin{array}{l}-0.001 \\
(0.007)\end{array}$ & $\begin{array}{l}-0.001 \\
(0.007)\end{array}$ & $\begin{array}{c}0.008 \\
(0.006)\end{array}$ & $\begin{array}{c}0.007 \\
(0.006)\end{array}$ \\
\hline $\begin{array}{l}\text { Stepfather Only } \\
\text { *Do }\end{array}$ & $\begin{array}{l}-0.010 \\
(0.020)\end{array}$ & $\begin{array}{l}-0.007 \\
(0.021)\end{array}$ & $\begin{array}{c}0.004 \\
(0.019)\end{array}$ & $\begin{array}{c}0.006 \\
(0.019)\end{array}$ & $\begin{array}{l}-0.000 \\
(0.000)\end{array}$ & $\begin{array}{l}-0.000 \\
(0.001)\end{array}$ & $\begin{array}{l}-0.012 \\
(0.008)\end{array}$ & $\begin{array}{l}-0.011 \\
(0.008)\end{array}$ & $\begin{array}{l}-0.008 \\
(0.005)\end{array}$ & $\begin{array}{l}-0.007 \\
(0.006)\end{array}$ \\
\hline RB Father*Talk & $\begin{array}{l}-0.005 \\
(0.003)\end{array}$ & $\begin{array}{l}-0.004 \\
(0.004)\end{array}$ & $\begin{array}{l}-0.002 \\
(0.003)\end{array}$ & $\begin{array}{l}-0.001 \\
(0.003)\end{array}$ & $\begin{array}{c}-0.002^{* * * *} \\
(0.001)\end{array}$ & $\begin{array}{c}-0.001 * \\
(0.001)\end{array}$ & $\begin{array}{l}-0.002 \\
(0.002)\end{array}$ & $\begin{array}{l}-0.002 \\
(0.002)\end{array}$ & $\begin{array}{l}-0.001 \\
(0.001)\end{array}$ & $\begin{array}{l}-0.000 \\
(0.001)\end{array}$ \\
\hline $\begin{array}{l}\text { NB Father Only } \\
\quad \text { *Talk }\end{array}$ & $\begin{array}{l}-0.000 \\
(0.005)\end{array}$ & $\begin{array}{c}0.001 \\
(0.005)\end{array}$ & $\begin{array}{c}0.003 \\
(0.004)\end{array}$ & $\begin{array}{c}0.004 \\
(0.004)\end{array}$ & $\begin{array}{l}-0.001 \\
(0.001)\end{array}$ & $\begin{array}{l}-0.000 \\
(0.002)\end{array}$ & $\begin{array}{l}-0.003 \\
(0.003)\end{array}$ & $\begin{array}{l}-0.002 \\
(0.003)\end{array}$ & $\begin{array}{l}-0.001 \\
(0.003)\end{array}$ & $\begin{array}{l}-0.000 \\
(0.003)\end{array}$ \\
\hline $\begin{array}{l}\text { Stepfather*Talk } \\
\text { (Dual) }\end{array}$ & $\begin{array}{l}-0.003 \\
(0.009)\end{array}$ & $\begin{array}{l}-0.003 \\
(0.009)\end{array}$ & $\begin{array}{c}0.002 \\
(0.006)\end{array}$ & $\begin{array}{c}0.003 \\
(0.006)\end{array}$ & $\begin{array}{c}0.000 \\
(0.003)\end{array}$ & $\begin{array}{c}0.001 \\
(0.003)\end{array}$ & $\begin{array}{l}-0.005 \\
(0.005)\end{array}$ & $\begin{array}{l}-0.005 \\
(0.005)\end{array}$ & $\begin{array}{l}-0.001 \\
(0.007)\end{array}$ & $\begin{array}{c}0.000 \\
(0.007)\end{array}$ \\
\hline $\begin{array}{l}\text { NB Father*Talk } \\
\text { (Dual) }\end{array}$ & $\begin{array}{l}-0.004 \\
(0.009)\end{array}$ & $\begin{array}{l}-0.004 \\
(0.009)\end{array}$ & $\begin{array}{l}-0.006 \\
(0.007)\end{array}$ & $\begin{array}{l}-0.006 \\
(0.007)\end{array}$ & $\begin{array}{c}0.004 \\
(0.004)\end{array}$ & $\begin{array}{c}0.004 \\
(0.004)\end{array}$ & $\begin{array}{c}0.004 \\
(0.005)\end{array}$ & $\begin{array}{c}0.004 \\
(0.005)\end{array}$ & $\begin{array}{l}-0.003 \\
(0.005)\end{array}$ & $\begin{array}{l}-0.002 \\
(0.005)\end{array}$ \\
\hline $\begin{array}{l}\text { Stepfather Only } \\
\text { *Talk }\end{array}$ & $\begin{array}{l}-0.006 \\
(0.018)\end{array}$ & $\begin{array}{l}-0.007 \\
(0.018)\end{array}$ & $\begin{array}{l}-0.002 \\
(0.015)\end{array}$ & $\begin{array}{l}-0.002 \\
(0.016)\end{array}$ & $\begin{array}{c}0.000 \\
(0.000)\end{array}$ & $\begin{array}{c}0.001 \\
(0.001)\end{array}$ & $\begin{array}{c}0.001 \\
(0.007)\end{array}$ & $\begin{array}{l}-0.000 \\
(0.007)\end{array}$ & $\begin{array}{l}-0.009 \\
(0.006)\end{array}$ & $\begin{array}{l}-0.009 \\
(0.006)\end{array}$ \\
\hline
\end{tabular}




\begin{tabular}{|c|c|c|c|c|c|c|c|c|c|c|}
\hline $\begin{array}{l}\text { Any } \\
\text { (Wave 1) }\end{array}$ & $\begin{array}{c}0.059 * * * \\
(0.007)\end{array}$ & $\begin{array}{c}0.053 * * * \\
(0.007)\end{array}$ & & & & & & & & \\
\hline $\begin{array}{l}\text { Property Crime } \\
\text { (Wave 1) }\end{array}$ & & & $\begin{array}{c}0.054^{* * *} \\
(0.007)\end{array}$ & $\begin{array}{c}0.052^{* * *} \\
(0.008)\end{array}$ & & & & & & \\
\hline $\begin{array}{l}\text { Violent Crime } \\
\text { (Wave 1) }\end{array}$ & & & & & $\begin{array}{c}0.011^{* *} \\
(0.005)\end{array}$ & $\begin{array}{c}0.010 * * \\
(0.005)\end{array}$ & & & & \\
\hline $\begin{array}{l}\text { Selling Drugs } \\
\text { (Wave 1) }\end{array}$ & & & & & & & $\begin{array}{c}0.055^{* * *} \\
(0.015)\end{array}$ & $\begin{array}{c}0.052 * * * \\
(0.015)\end{array}$ & & \\
\hline $\begin{array}{c}\text { Gang Fighting } \\
\text { (Wave 1) }\end{array}$ & & & & & & & & & $\begin{array}{c}0.021^{* * *} \\
(0.005)\end{array}$ & $\begin{array}{c}0.020 * * * \\
(0.005)\end{array}$ \\
\hline $\begin{array}{l}\text { Doing things } \\
\text { with mother }\end{array}$ & & $\begin{array}{c}-0.007 * * \\
(0.003)\end{array}$ & & $\begin{array}{c}-0.006 * * \\
(0.003)\end{array}$ & & $\begin{array}{c}0.000 \\
(0.001)\end{array}$ & & $\begin{array}{l}-0.002 \\
(0.002)\end{array}$ & & $\begin{array}{l}-0.001 \\
(0.001)\end{array}$ \\
\hline $\begin{array}{l}\text { Talking to } \\
\text { Mother }\end{array}$ & & $\begin{array}{c}0.002 \\
(0.003)\end{array}$ & & $\begin{array}{c}0.000 \\
(0.003)\end{array}$ & & $\begin{array}{l}-0.000 \\
(0.001)\end{array}$ & & $\begin{array}{c}0.002 \\
(0.002)\end{array}$ & & $\begin{array}{l}-0.001 \\
(0.001)\end{array}$ \\
\hline $10 \mathrm{k} \leq \mathrm{Inc}<25 \mathrm{k}$ & & $\begin{array}{c}0.029^{* *} \\
(0.014)\end{array}$ & & $\begin{array}{c}0.015 \\
(0.012)\end{array}$ & & $\begin{array}{c}0.007 \\
(0.005)\end{array}$ & & $\begin{array}{c}0.011 \\
(0.007)\end{array}$ & & $\begin{array}{l}-0.001 \\
(0.006)\end{array}$ \\
\hline $25 \mathrm{k} \leq \mathrm{Inc}<50 \mathrm{k}$ & & $\begin{array}{c}0.012 \\
(0.015)\end{array}$ & & $\begin{array}{c}0.007 \\
(0.013)\end{array}$ & & $\begin{array}{c}0.006 \\
(0.005)\end{array}$ & & $\begin{array}{c}0.002 \\
(0.006)\end{array}$ & & $\begin{array}{l}-0.001 \\
(0.006)\end{array}$ \\
\hline $50 \mathrm{k} \leq \mathrm{Inc}<75 \mathrm{k}$ & & $\begin{array}{l}-0.001 \\
(0.014)\end{array}$ & & $\begin{array}{l}-0.004 \\
(0.012)\end{array}$ & & $\begin{array}{c}0.000 \\
(0.004)\end{array}$ & & $\begin{array}{c}0.003 \\
(0.008)\end{array}$ & & $\begin{array}{l}-0.003 \\
(0.006)\end{array}$ \\
\hline Inc $\geq 75 k$ & & $\begin{array}{c}0.015 \\
(0.017)\end{array}$ & & $\begin{array}{l}-0.001 \\
(0.015)\end{array}$ & & $\begin{array}{c}0.004 \\
(0.005)\end{array}$ & & $\begin{array}{c}0.013 \\
(0.008)\end{array}$ & & $\begin{array}{c}0.000 \\
(0.006)\end{array}$ \\
\hline $\begin{array}{l}\text { Demographic } \\
\text { controls }\end{array}$ & No & Yes & No & Yes & No & Yes & No & Yes & No & Yes \\
\hline Observations & 6,741 & 6,741 & 6,741 & 6,741 & 6,736 & 6,736 & 6,732 & 6,732 & 6,731 & 6,731 \\
\hline R-squared & 0.02 & 0.03 & 0.02 & 0.02 & 0.01 & 0.01 & 0.01 & 0.02 & 0.01 & 0.01 \\
\hline
\end{tabular}

Standard errors are clustered at the school level are shown in parentheses. A *, **, or *** indicates significance at the $90 \%$, 95\%, or 99\% levels, respectively.

Note: RB father indicates residential, biological father; NB father indicates non-residential, biological father; and all stepfathers are residential. Dual indicates the presence of both a NB father and a stepfather. "Do" and "Talk" indicate doing things with and talking to adolescents, respectively. 